I N TER N A T I O N A L M O NETAR Y F U N D

Africa Department

Sustaining More Inclusive Growth in the Republic of Congo

IMF staff team led by Dalia Hakura and composed of Adrian Alter, Matteo Ghilardi, Rodolfo Maino, Cameron McLoughlin, and Maximilien Queyranne 
I N TER NATIONALMONETARY FUND

African Department

\section{Sustaining More Inclusive Growth in the Republic of Congo}

IMF staff team led by Dalia Hakura and composed of Adrian Alter, Matteo

Ghilardi, Rodolfo Maino, Cameron Mcloughlin, and Maximilien Queyranne 
Copyright $\odot 2014$

International Monetary Fund

\section{Cataloging-in-Publication Data Joint Bank-Fund Library}

Sustaining more inclusive growth in the Republic of Congo / prepared by an IMF staff team led by Dalia Hakura and composed of Adrian Alter, Matteo Ghilardi, Rodolfo Maino, Cameron McLoughlin, and Maximilien Queyranne. - Washington, DC : International Monetary Fund, 2014.

pages ; $\mathrm{cm}$

Africa Department. Includes bibliographical references and index. ISBN: 978-1-49831-770-2 (paper)

ISBN: 978-1-49834-826-3 (pdf)

1. Economic development - Congo (Brazzaville) I. Hakura, Dalia S. II. Alter, Adrian. III. International Monetary Fund. IV. International Monetary Fund. African Department. V. International Monetary Fund. Research Department. VI. International Monetary Fund. Strategy, Policy, and Review Department. VII. International Monetary Fund. Fiscal Affairs Department.

HC980.S87 2014

The African Departmental Paper Series covers research on sub-Saharan Africa conducted by IMF staff, particularly on issues of broad regional or cross-country interest. The views expressed in this paper are those of the author(s) and do not necessarily represent the views of the IMF, its Executive Board, or IMF management.

Publication orders may be placed online, by fax, or through the mail:

International Monetary Fund, Publication Services

P.O. Box 92780, Washington, DC 20090, U.S.A.

Tel. (202) 623-7430 Fax: (202) 623-7201

E-mail: publications@imf.org

www.imfbookstore.org

www.elibrary.imf.org 


\section{Contents}

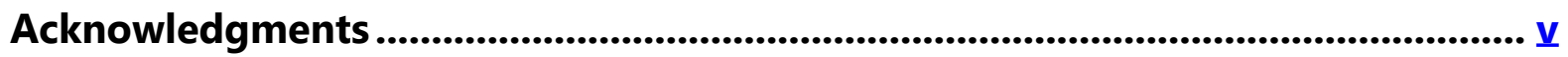

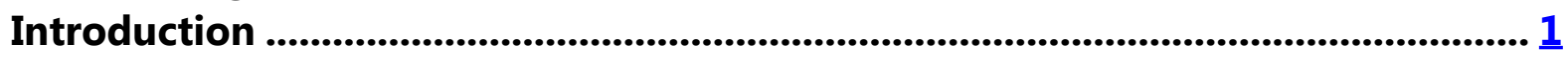

Public Investment, Natural Resources, and Debt Sustainability ............................ $\underline{5}$

Equitable Fiscal Consolidation ........................................................................11

Financial Sector: Risks, Development, and Inclusion .............................................. $\underline{23}$

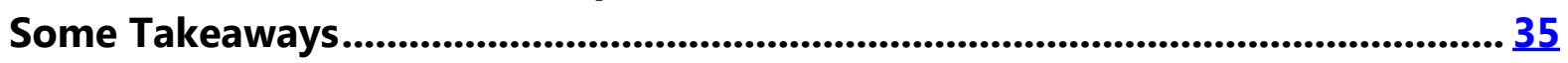

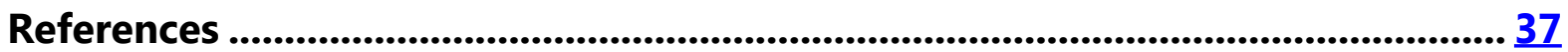


This page intentionally left blank 


\section{Acknowledgments}

This paper was written by a staff team led by Dalia Hakura. The main contributor to Chapter 1 is Matteo Ghilardi (RES/SPR). The main contributor to Chapter 2 is Maximilien Queyranne (FAD), who received helpful comments from Mario Mansour and Patrick Petit (both FAD). The main contributors to Chapter 3 are Adrian Alter and Rodolfo Maino (AFR). Research assistance was provided by Zaki Dernaoui. Administrative assistance was provided by Margaret Attey and Light Koulefianou. The paper was prepared in the context of the Republic of Congo 2014 Article IV consultation, and the preliminary results were discussed with Congo authorities during the 2014 Article IV consultation mission that took place May 13-26, 2014. 
This page intentionally left blank 


\section{Introduction}

The Republic of Congo is at a critical juncture. The country's debt situation improved dramatically in 2010 as a result of debt relief through the IMF and World Bank Heavily Indebted Poor Countries/Multilateral Debt Relief Initiative. Successive years of high international oil prices have yielded large oil revenues that have allowed the government to boost spending while setting aside substantial fiscal savings and accumulating foreign exchange reserves. However, poverty and inequality remain comparatively high, despite robust economic growth and high government spending in recent years.

- Between 2005 and 2011, the poverty rate declined by only about 4 percentage points to 46.5 percent, still far above Congo's target of reducing poverty to 35 percent by 2015 under the United Nations Millennium Development Goals. Moreover, the top quintile of Congo's population accounts for more than 52 percent of total household income.

- Given the high level of government spending in recent years, there is ample scope to further reduce poverty. For instance, government spending of oil revenues, net of savings deposited at the Bank of Central African States and in China, averaged about $\$ 700$ a year per capita. If this amount had been distributed directly to the population, each citizen would have received close to $\$ 2$ a day and poverty would have been eradicated. ${ }^{1}$ Although such an extreme solution would initially leave the government without adequate resources to carry out its core activities, including providing basic public goods, it illustrates the magnitude of the government's revenue from oil, annual government spending, and the potential to raise the standard of living through more efficient spending.

\section{Given the country's limited oil reserves, it is imperative for Congo to gradually reduce its dependence on oil revenues and put the economy on a medium-term path of higher}

\footnotetext{
${ }^{1}$ The national poverty line was about US\$1.6 (CFAF 839) a day in 2005 (IMF 2012).
} 
sustainable and inclusive non-oil growth. This requires the implementation of an extensive agenda of macroeconomic and structural reforms.

The Congo government's Poverty Reduction Strategy Paper (PRSP) for 2012-16 aspires to reduce poverty, achieve inclusive growth and employment, and put the country on a path to becoming a bona fide emerging market. The government is in its third year of implementing the National Development Plan (NDP) encompassed by the PRSP. Under the NDP, the authorities are implementing an ambitious public investment program that aims to address large social and infrastructure gaps and diversify the economy.

In recent years government spending has been well above the average for other African and Middle Eastern oil exporters. Government expenditure constituted 91 percent of non-oil GDP in 2013, and Congo's non-oil fiscal balance reached 61.8 percent of non-oil GDP. In addition to spending related to the NDP_-aimed at attaining the government's growth and inclusiveness objectives, the government is facing spending pressure related to the 2015 All Africa Games, domestic arrears, and the 2016 presidential election.

The challenges faced by the Congo authorities are compounded by the limited size of the country's oil reserves. Congo's proven oil reserves are estimated at about 1.6 billion barrels. Production averaged about 93 million barrels a year in 2012 and 2013 . According to Congo authorities' estimates, after peaking at 118 million barrels in 2017, oil production is estimated to decline to about 18 million barrels by 2030. This would make it impossible to sustain the high levels of government spending of the past few years. Therefore, in order to preserve macroeconomic stability, the projected depletion of oil reserves calls for fiscal adjustment over the medium to long term. Given the current very large non-oil fiscal deficit, this will have a major impact on fiscal aggregates. Nevertheless, the authorities have indicated that they are committed to this fiscal adjustment.

This paper is composed of three chapters examining different aspects of Congo's challenge to managing its natural resource revenue and attaining sustained inclusive growth, as follows:

Section I analyzes the design of public investment paths that can foster economic growth while ensuring fiscal and debt sustainability in the Republic of Congo in view of its projected decline in oil revenue. It applies the Debt, Investment, Growth and Natural Resources (DIGNAR) model developed by the IMF's Research Department. It considers the effects of different public investment paths, levels of public investment efficiency, and oil revenue paths on the buildup of public capital, savings, and government debt. The section highlights the risks to the country's fiscal position from scaling up public investment and adverse shocks to oil prices or production in view of the projected decline in the ratio of oil revenue to GDP. The section also illustrates that structural reforms and public financial management reforms that improve the efficiency of public investment can increase the stock of productive capital and growth without adversely affecting government savings and government-debt-to-GDP ratios.

Section II discusses the role that fiscal policy can play in reducing poverty and inequality in the Republic of Congo during a period of fiscal consolidation. A strategy is proposed that could mitigate the adverse effects of fiscal consolidation on inequality and poverty. The large 
fiscal adjustment that is needed should be achieved first and foremost by a rationalization of spending. In addition, efforts should be made to raise non-oil revenues in an equitable way.

Section III discusses critical issues in the Republic of Congo related to financial inclusion and development that have been found to have a significant impact on poverty and shared economic growth. Lack of credible collateral and inadequate protection of creditors' rights are identified as key impediments to financial sector development. In addition, drawing on comparative statistics for Congo and peer countries in sub-Saharan Africa, it is evident that financial access in Congo is still among the least inclusive in the Central African Economic and Monetary Community (CEMAC) and Communauté Financière d'Afrique (CFA) franc area. In this context, the section highlights the role of new technologies in the promotion of financial inclusion, particularly the potential of mobile banking to further enhance access to financial services.

Finally, Section IV offers some takeaways. 
This page intentionally left blank 


\section{Public Investment, Natural Resources, and Debt Sustainability}

The Republic of Congo's economy is heavily dependent on oil. Currently, oil production accounts for 58 percent of GDP, oil exports account for 78 percent of exports, and the government's revenues from oil represent 74 percent of total fiscal revenues. The government is drawing on its oil revenues to implement an ambitious investment plan to develop the economy and address social and infrastructure gaps.

While oil revenues can help accelerate the Republic of Congo's development, the expected decline in oil production will lead to declining government revenue from oil over the medium term to the point that these revenues will be relatively insignificant by the early 2030s. The projected decline poses challenges to designing sustainable public investment paths that can be properly financed and that allow a buildup of savings to support government spending in the post-oil era. This is of crucial importance given the current high level of government spending, concerns about the absorptive and implementation capacity of government spending, and spending pressure related to the hosting of the All Africa Games in Brazzaville in 2015 and the 2016 presidential election.

The DIGNAR model provides a framework for analyzing the feasibility of public investment plans such as the one proposed by the Congo authorities. The model is designed to analyze the nexus of natural resource revenue management, public investment, and public debt. The analytical framework is based on Buffie and others 2012, Berg and others 2013, and Melina, Yang, and Zanna 2014 and includes the natural resource sector, investment efficiency, limited absorptive capacity, Dutch disease, and a detailed fiscal specification reflecting the operation of fiscal buffers. Taking resource revenues and public investment policy as given, the framework can simulate the macroeconomic outcomes of investing resource revenue, taking into account the investment-growth linkage and the feedback effect on nonresource revenue.

The DIGNAR model provides a stylized representation of a small open economy with oil production and public investment needs, such as Congo's economy. These are the particular features of the model: 
- $\quad$ There are two types of households. Optimizing households have access to financial markets and can acquire international bonds with portfolio adjustment costs, which restricts the degree of capital account openness. The private sector pays a premium on foreign debt above the interest rate that the government pays on its external debt. Nonoptimizing consumers or "rule-of-thumb" consumers are liquidity constrained and use all their disposable income in each period.

- $\quad$ There are three production sectors. Traded and nontraded goods are produced according to a Cobb-Douglas production function with three inputs: labor, private capital, and public capital. The difference between these two sectors lies in the modeling of technological progress. Such progress is assumed to be exogenous in the nontraded sector; in the traded sector it is subject to learning-by-doing externalities and depends positively on previousperiod output. The intuition is that once traded-sector production starts falling, knowledge and skills can be lost. The third sector produces oil and is assumed to be exogenously set, with both price and quantities taken as given.

- The capital formation process is subject to absorptive capacity constraints and government inefficiency. In particular, effective government investment is just a fraction of government expenditure on investment. Furthermore, to capture the idea of rising investment costs because of absorptive-capacity constraints, investment efficiency is assumed to fall when the expenditure level exceeds a certain threshold.

- $\quad$ The government finances its consumption and investment expenditure with taxes, debt, and savings in the sovereign wealth fund (SWF). ${ }^{2}$ In particular, taxes are collected from the oil and non-oil sectors. Foreign debt is subject to a risk premium that depends on the stock of external debt. In every period, the government can choose to close the fiscal gap with an increase in taxes and/or in debt, as well as by drawing down savings. In this paper, savings in the SWF refers to government savings at the regional central bank (BEAC, in the Saving for Future Generations Fund and other funds) and government deposits abroad.

\section{Simulations consider several scenarios for public investment and its efficiency and oil}

revenues. In particular, three scenarios with different paths for public investment are examined:

- Baseline scenario: This scenario is based on the current projections. Public capital investment averages 16 percent of GDP during 2014-32. Moreover, the debt-to-GDP ratio averages 31 percent and oil revenues decrease from 33 percent in 2014 to about 2.5 percent of GDP in 2032.

- Scaled-up investment scenario: This scenario analyzes the implications of a large scale-up of public investment as discussed in IMF 2014b. Public investment peaks at about 35 percent of GDP in 2018 before declining. The path for public investment in this scenario follows the authorities' projected oil-production path.

- High investment until 2017 scenario: In this scenario public investment stays constant in percent of GDP until 2017 and then declines to the projected path of the baseline scenario.

\footnotetext{
${ }^{2}$ This section uses "resource fund" as a synonym for SWF.
} 
Two additional scenarios are considered: (1) the baseline scenario but with an increase in public investment efficiency as a result of structural reforms and improvements in public financial management (PFM); and (2) a scenario like the high investment until 2017 scenario but with lower oil revenues because of an adverse shock to oil prices (and/or oil production).

The baseline scenario delivers the best outcome in terms of debt sustainability and accumulation of financial assets in the SWF. Figure 1 shows that the projected path of public investment delivers a sustainable and sizable accumulation of public capital. ${ }^{3}$ At the same time, given the projected oil revenues, it allows for a sustained increase in savings in the SWF. There is also a mild but sustainable increase in the level of public debt in the long run owing to the government's policy of continuing to finance investments with concessional foreign borrowing. ${ }^{4}$ This produces an increase in non-oil GDP as well as an increase in private investment.

\section{Figure 1. Baseline Scenario}
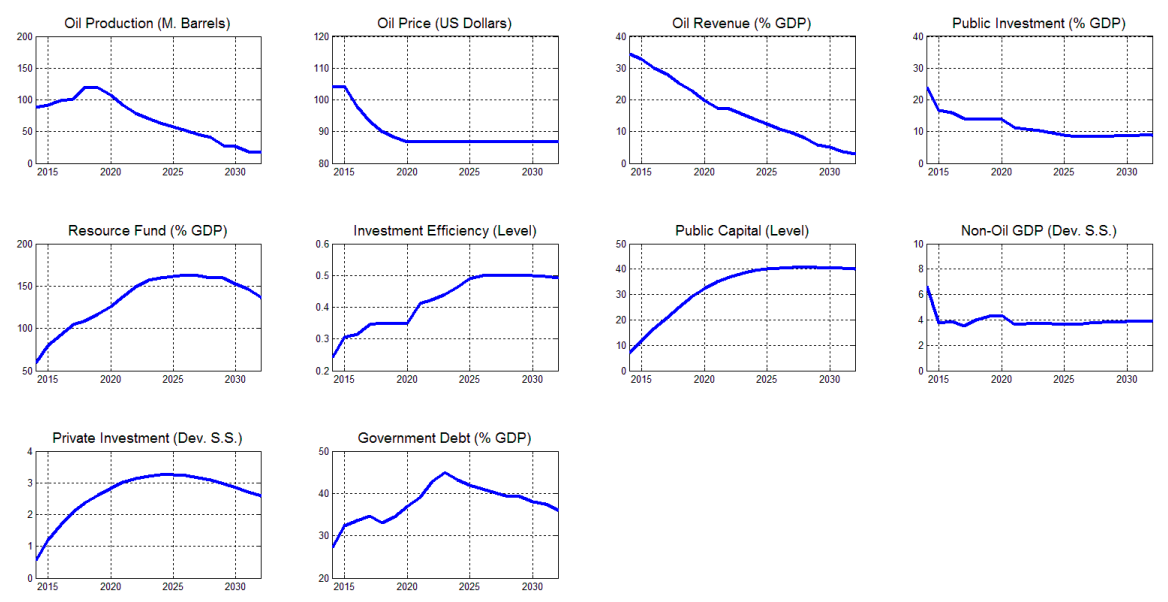

Source: Author's simulations.

The scaled-up investment scenario and the scenario with high investment until 2017 illustrate the dangers of a more pronounced scaling up of public investment. Figure 2 shows that scaling up public investment to 35 percent of GDP lowers the efficiency of investment and results in an unsustainable level of public capital. Higher investment initially results in a larger buildup of capital stocks, but without sufficient investment to cover recurrent costs, public capital begins to depreciate in future periods. Furthermore, this causes a quick erosion of the SWF and puts public debt on an unsustainable path. Similarly, maintaining public

\footnotetext{
${ }^{3}$ The variables are in percent deviation from a trend-growth path, unless specified otherwise in parentheses.

${ }^{4}$ The predicted level of debt is slightly higher compared with the projected value of the staff report baseline value. This is caused by the presence of domestic and concessional debt in the simulations.
} 
investment constant until 2017 at about 25 percent of GDP as in the high investment until 2017 scenario produces limited benefits compared with the baseline scenario while contributing to an unsustainable level of capital and erosion in the SWF (see Figure 3). The increase in investment is more inefficient and produces only a mild increase in the stock of public capital and comes with a high cost, as the SWF is almost half the level observed in the baseline.

\section{Figure 2. Scaled-Up Investment Scenario}
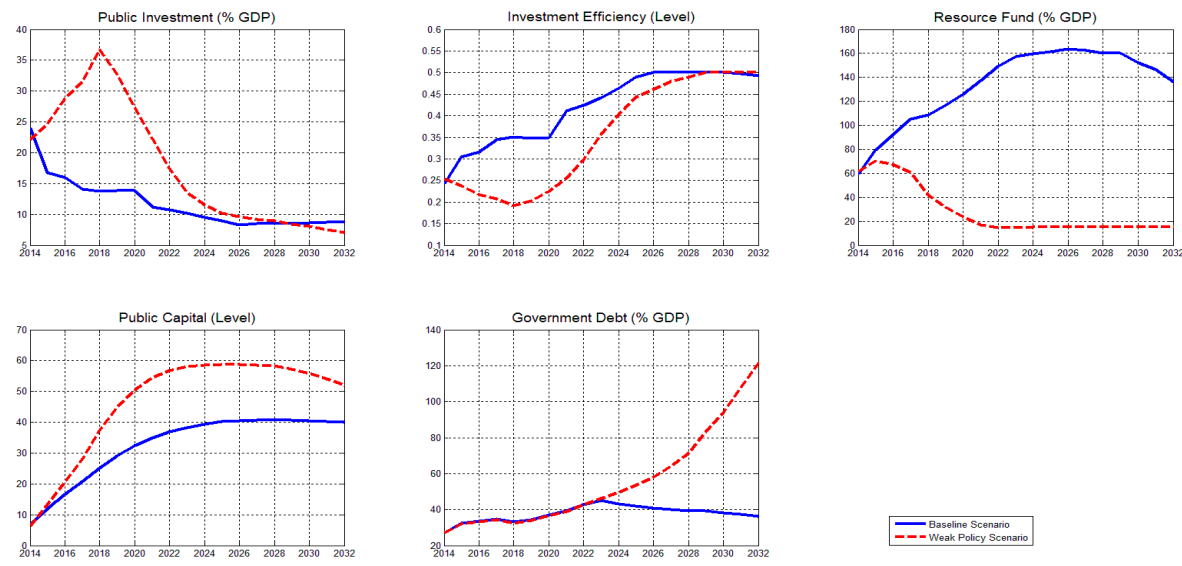

Source: Author's simulations.

Figure 3. Baseline Scenario with High Investment until 2017
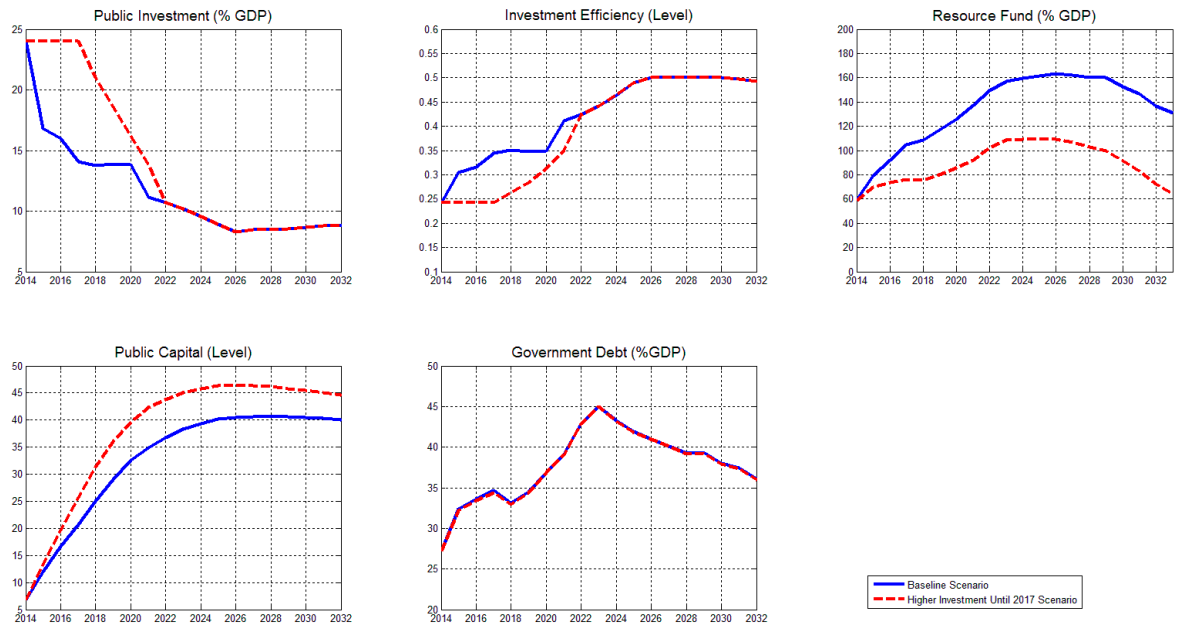

Source: Author's simulations. 
Structural reforms and PFM reforms could play an important role in the country's development. The gains from improvements in the business climate and the government's policy implementation capacity are illustrated in Figure 4. The resulting increase in the efficiency of investment starts from the same level as the baseline scenario and rises consistently over time. This captures the fact that strengthening policy frameworks, including PFM, takes time to be reflected in better policy outcomes. Simulations indicate that an increase in efficiency produces a sustainable and higher level of public capital without affecting SWF savings and the ratio of government debt to GDP.

Figure 4. Baseline Scenario with Higher Public Investment Efficiency
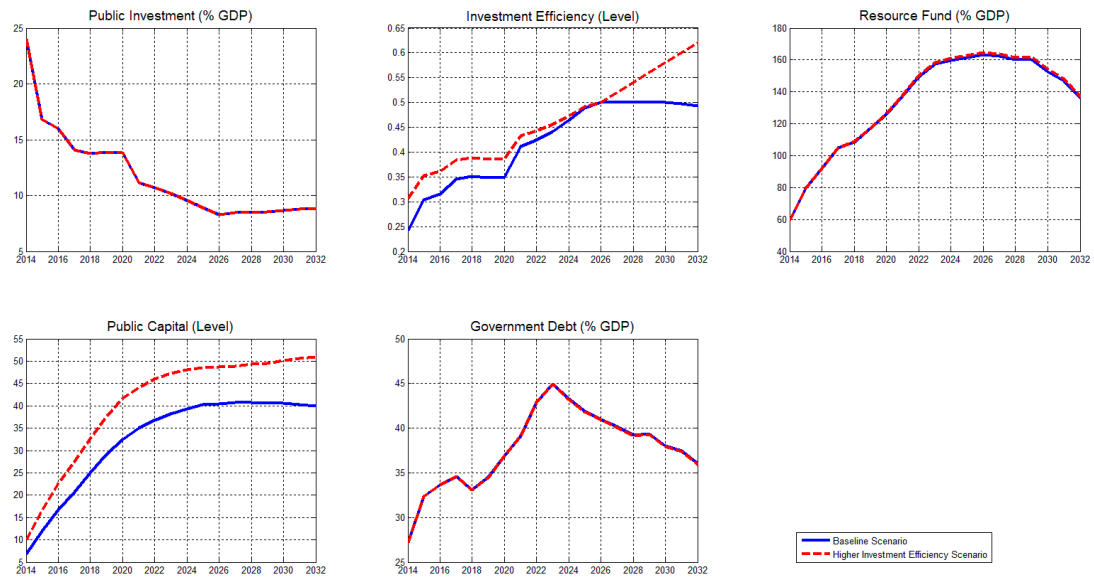

Source: Author's simulations.

\begin{abstract}
Uncertainty about future oil revenues poses downside risks that could undermine the country's fiscal position, particularly in the scenario in which adjustment of public investment spending is postponed. Figure 5 shows that an oil price shock has a negative impact on oil revenues and results in quick depletion of the SWF to the minimum needed for the Republic of Congo to support the pegged exchange rate arrangement (assumed to be 15 percent of GDP). Consequently, the debt-to-GDP ratio increases to nearly 60 percent of GDP by 2032. A 20 percent lower oil price in the medium term results in reduction of the resource fund by almost three-quarters of the baseline level at the end of the period. These findings are analogous for an adverse shock on oil production that leads to the same decline in the path of oil revenue.
\end{abstract}


Figure 5. A Decrease in Oil Revenues
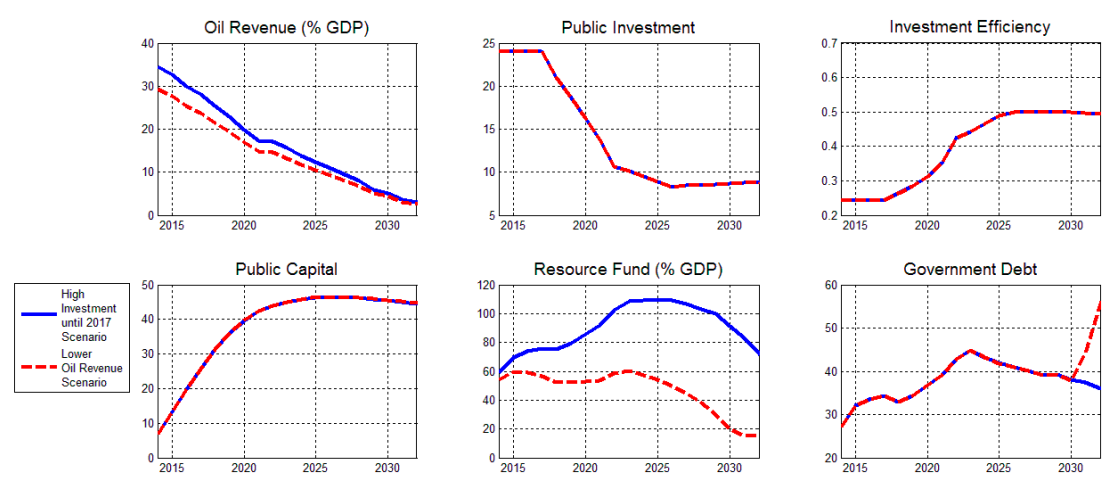

Source: Author's simulations

In sum, the simulations highlight the importance of a prudent approach to public investment. The public investment path in the baseline scenario would be the most appropriate in terms of ensuring sustainability of public capital and debt as well as building up savings in the resource fund. Higher public capital can be achieved with structural reforms and PFM reforms rather than with scaled-up public investment, which puts pressure on the resource fund and on public debt. Furthermore, the simulations highlight the risks to the fiscal position of the country. 


\section{Equitable Fiscal Consolidation}

High levels of public spending and the depletion of oil reserves call for a fiscal adjustment in the Republic of Congo over the medium to long term. Estimates of proven oil reserves suggest that oil revenues will decline decisively after 15 years. ${ }^{5}$ Given the current very large nonoil fiscal deficit, this will have a major impact on fiscal aggregates. IMF 2014b proposes a fiscal adjustment path that aims to cut the non-oil primary deficit in half, to about 30 percent of nonoil GDP, by 2019 — with a further reduction in the medium to long term. This reduction in the non-oil deficit should be achieved first and foremost by more efficient and targeted spending. In addition, effort should be made to raise non-oil revenues in an equitable way. In this context, this chapter proposes a strategy that could mitigate the adverse effect of fiscal consolidation on inequality and poverty. The first section reviews income inequality and poverty trends in Congo and describes the redistributive role of fiscal policy. The second section discusses how fiscal consolidation can contribute to achieving distributional objectives through tax and expenditure policy reforms.

\section{Poverty and Inequality: The Role of Fiscal Policy}

Poverty and inequality are comparatively high in the Republic of Congo. Poverty in Congo was significantly higher in 2011 compared with countries with similar GDP per capita ${ }^{6}$ (Figure 6), and Congo's poverty scores are similar or higher to those of other sub-Saharan African (SSA) countries with significantly lower income. Although the poverty rate went down from 50.7 percent in 2005 to 46.5 percent in 2011, the number of poor people increased from 1.8 million

\footnotetext{
${ }^{5}$ Average production in 2012 and 2013 was 93 million barrels a year. After peaking at 118 million barrels in 2017, oil production is estimated to decline to about 18 million barrels by 2030 .

${ }^{6}$ This analysis considers countries that have a per capita GDP (in purchasing-power-parity U.S. dollars) between 25 percent above and 25 percent below that of Congo. The analysis is based on internationally comparable data, for which the latest observation is 2011 or 2012.
} 
to 1.9 million. ${ }^{7}$ In addition, poverty is widespread in rural areas (75.6 percent) and has increased sharply since 2005 (57.4 percent), whereas it has declined significantly in urban areas (from 53.4 to 29.4 percent in Brazzaville). As regards income inequality, the Gini coefficient for disposable income declined in Congo between 2005 and 2011 and is now equivalent to the average for SSA countries (0.44). ${ }^{8}$ But the Gini remains above that of countries with similar income levels (0.39). As a result, Congo's United Nations Human Development Index score is significantly below the average of countries with similar GDP per capita and has improved more slowly since 2005.

Figure 6. Selected Poverty and Human Development Indicators

Poverty Head Count Ratio at National Level (2011, percent of population $)^{1 /}$

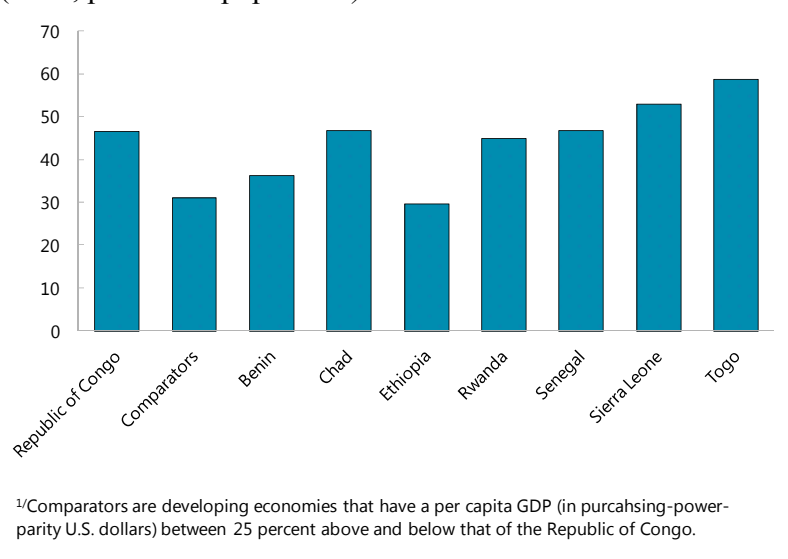

Source: World Bank, World Development Indicators database.

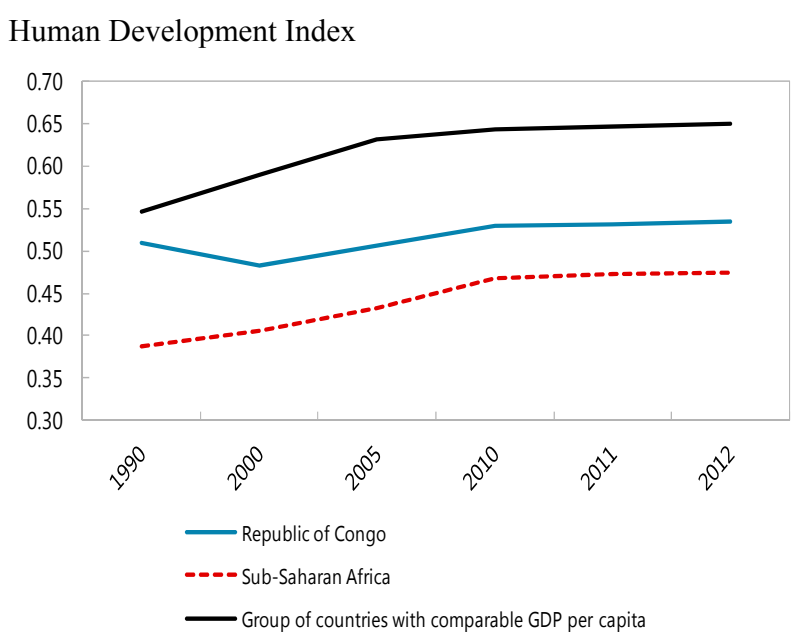

Source: United Nations Development Programme, Human Development Index.

Total government revenue and spending are particularly high in the Republic of Congo. Total government revenue represented 111.7 percent of non-oil GDP in 2013, significantly higher than in most oil-exporting low-income countries (Figure 7). Oil revenue accounted for almost 75 percent of government revenue (at 34.5 percent of GDP). As a result, total government spending was also significantly higher than for comparators, with the exception of Equatorial Guinea.

\footnotetext{
${ }^{7}$ Congo's population grew at an annual average rate of 3 percent over the same period.

${ }^{8}$ The latest available international Gini coefficient is for 2005. For comparative analysis, the 2011 figure was estimated by applying the percentage point improvement between 2005 and 2011 taken from the national household survey, for which the Gini coefficient went down from 0.42 to 0.39 over this period.
} 
Figure 7. Fiscal Aggregates in 2013

(Percent of non-oil GDP)

General Government Total Revenue

General Government Total Expenditure
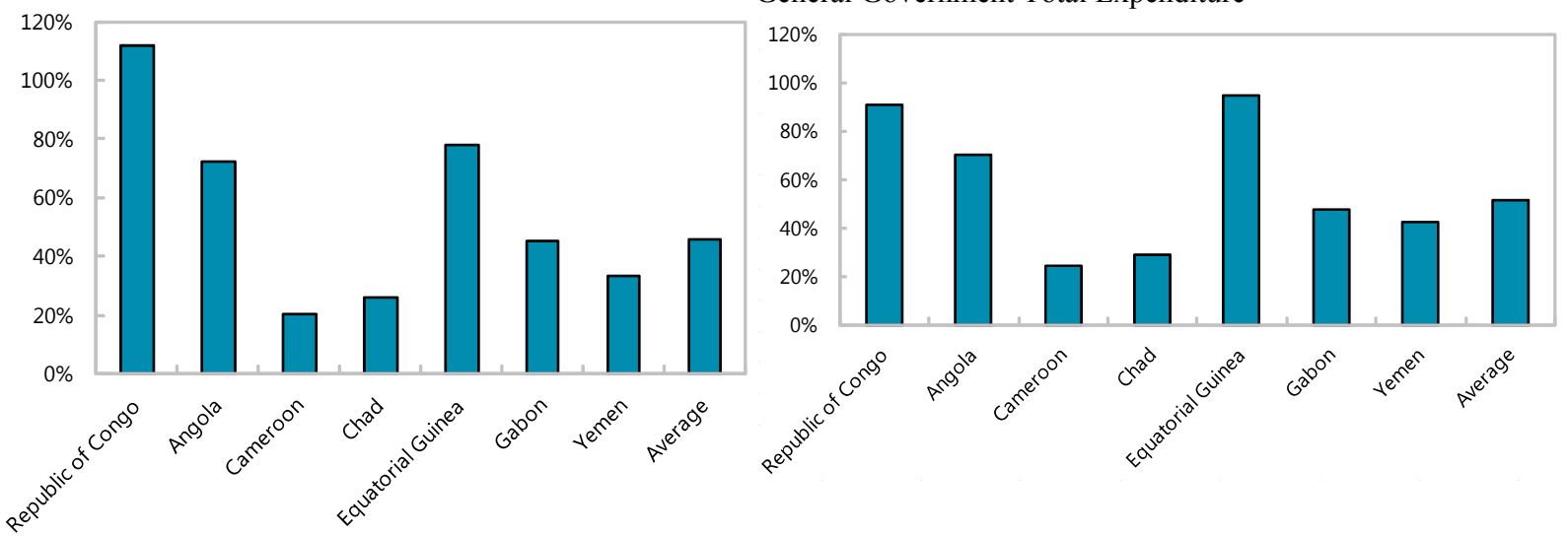

Source: IMF staff estimates.

Source: IMF staff estimates.

However, the low level of tax revenue significantly reduces the redistributive role of tax policy. Tax revenue accounted for only 6.7 percent of GDP in 2010, much lower than the average for SSA countries (17.9 percent) and countries with comparable income levels (23.4 percent). Tax policy can, therefore, play only a marginal role in achieving redistributive goals in Congo. In addition, the tax structure favors consumption taxes, which are less progressive than income and wealth-related taxes. Income tax and property tax revenues (classified as "other taxes") are particularly limited, even compared with other SSA countries (Figure 8).

\section{Figure 8. Composition of Government Revenues}

Share of Total Government Revenues

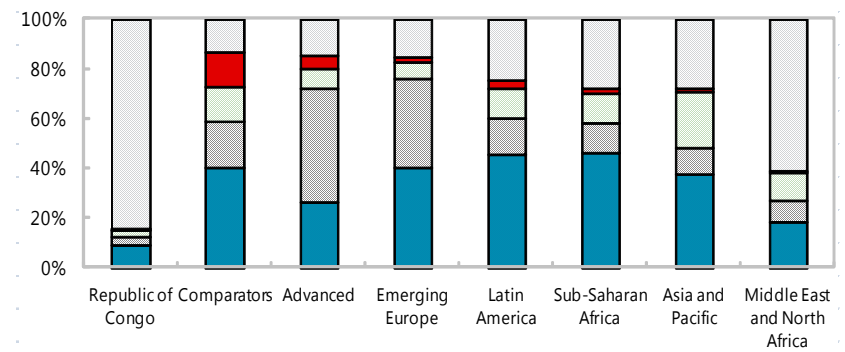

口Indirect $\square$ Income Tax Revenue $\square$ Corporate Income Tax Revenue $\square$ Other taxes $\square$ Other revenue
Composition of Tax Revenues (percent of GDP)

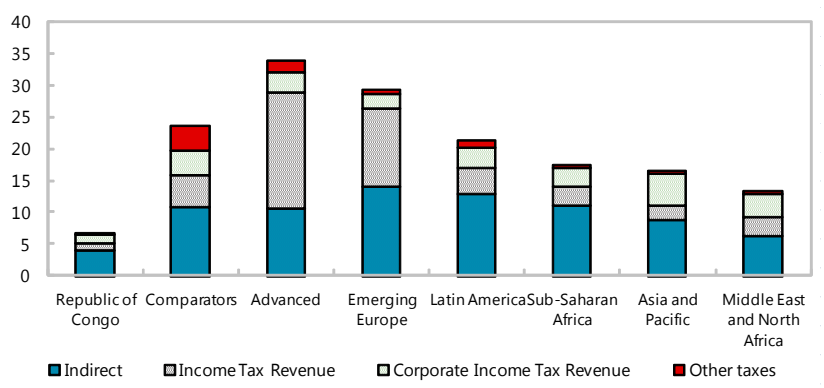

Source: IMF staff estimates. 
Recent personal income tax reforms have not strengthened progressivity. The government reformed the personal income tax system in 2011 and 2013 by reducing the rate of each bracket by 5 percentage points (except the first bracket, which was maintained at 1 percent) and increasing the size of the four lowest brackets. ${ }^{9}$ The IMF staff estimates that this reform is mostly regressive because its benefits accrue more to higher-income families and single people with intermediate incomes (Table 1). These results reflect (1) the larger impact of the reduction of the tax rates than of the increase of the lowest brackets, which benefits more low-income households; and (2) the large tax deductions on salary income and the family tax system, because they are proportional to income.

\section{Social spending was marginal in 2010 and largely crowded out by significant energy}

subsidies. Social spending was much lower than in most SSA countries and countries with similar income levels (Figure 9). In Congo, fuel subsidies were higher in 2010 (3.59 percent of GDP) than aggregate spending on education, health, and social protection (2.51 percent of GDP) and significantly larger than in the SSA region (1.38 percent). Large fuel subsidies may reflect the desire to share the country's oil wealth through the provision of petroleum products at prices below those in the international market, even if refined oil is imported. But such subsidies have a large fiscal cost and crowd out social spending. Fuel subsidies are usually poorly targeted, and benefits accrue mostly to higher-income groups, because they consume the most. In the SSA region, 44.2 percent of benefits from fuel subsidies in 2010 accrued to the richest 20 percent of the population, whereas the poorest 20 percent received only 7.8 percent (Arze del Granado, Coady, and Gillingham 2010).

\section{Table 1. Impact of Recent Personal Income Tax Reforms on the Average Tax Rate (Percentage points)}

\begin{tabular}{lccc}
$\begin{array}{c}\text { Taxable Income Levels } \\
\text { (CFA francs) }\end{array}$ & $\begin{array}{c}\text { Change in the Average } \\
\text { Tax Rate for a Single } \\
\text { Person }\end{array}$ & $\begin{array}{c}\text { Change in the Average } \\
\text { Tax Rate for a Family } \\
\text { with Two Children }\end{array}$ & $\begin{array}{c}\text { Change in the Average } \\
\text { Tax Rate for a Family } \\
\text { with Four Children }\end{array}$ \\
\hline 232,000 & 0 & 0 & 0 \\
732,000 & 5.8 & 0 & 0 \\
$2,000,000$ & 6.2 & 6.1 & 7.6 \\
$5,500,000$ & 6.2 & 6.4 & 7.2 \\
$15,000,000$ & 4.8 & 6.4 & 7.2
\end{tabular}

Source: IMF estimates.

\footnotetext{
${ }^{9}$ Tax brackets are as follows (2014 budget act): 1 percent (CFA 0-0.46 million), 10 percent (CFA 0.46-1 million), 25 percent (CFA 1-3 million), 40 percent (CFA 3 to 8 million), and 45 percent (more than CFA 8 million).
} 
The government has stepped up its investment sharply to address infrastructure gaps. Public capital spending rose from 6.1 percent of GDP in 2006 to 18.8 percent in 2010 (Figure 10). As a result, the public capital stock in the Republic of Congo has increased since 2006 and was significantly higher than comparators (GDP per capita) in 2011, including that of oil-exporting $\mathrm{LICs}^{10}$ (Figure 10). According to the National Development Plan, the vast majority of capital spending for the period 2012-16 is to be allocated to infrastructure (51.7 percent in 2014) and economic development (16.7 percent). However, the share of capital expenditure allocated to social development should be raised from 11.7 percent to 16.7 in 2014 . According to the 2014 budget act, social ministries are to receive about 14 percent of government capital expenditure.

\section{Figure 9. Composition of Spending}

Composition of Social Spending in 2010 (percent GDP)

Fuel Subsidies and Social Spending in 2010 (percent GDP)
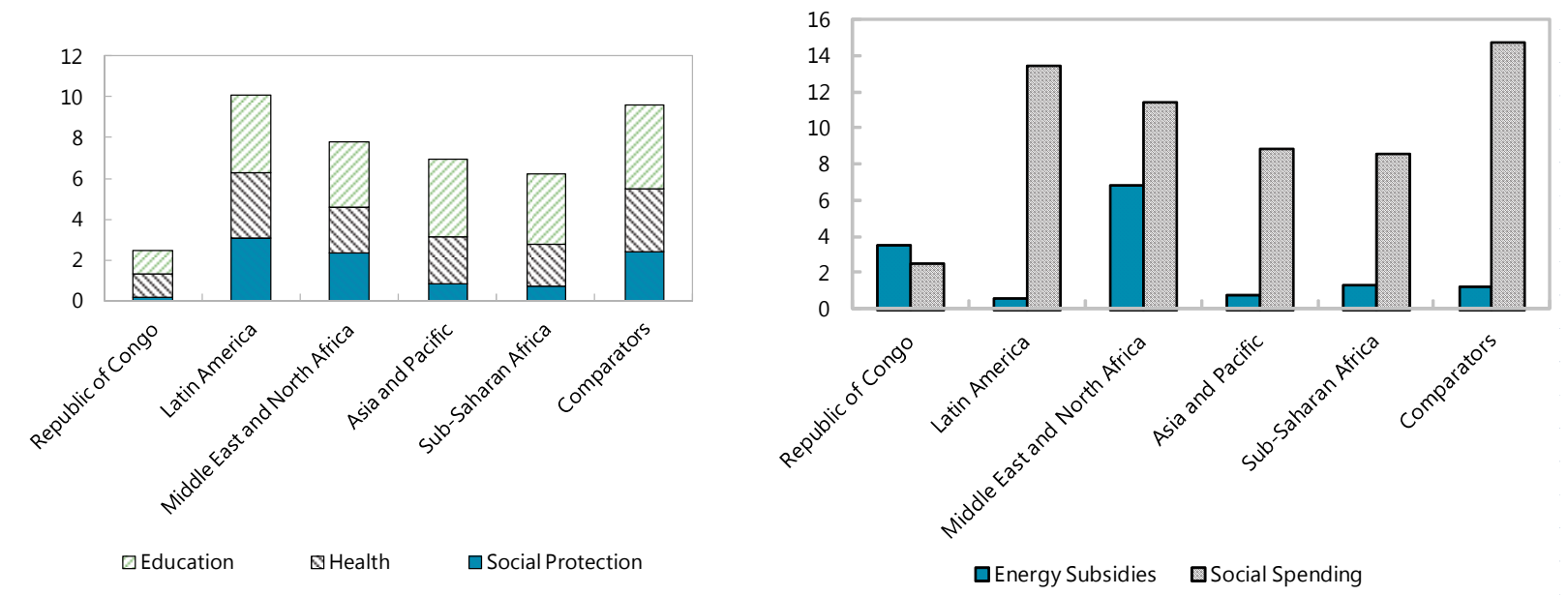

Source: IMF staff estimates.

Source: IMF staff estimates.

${ }^{10}$ Cameroon, Chad, Sudan, Vietnam, Yemen. 


\section{Figure 10. Capital Expenditure and Public Capital Stock}

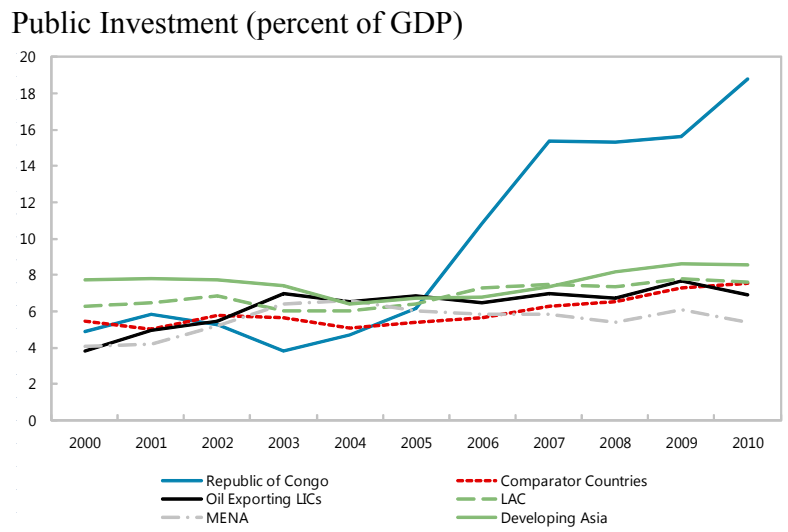

Sources: Center for International Comparisons; Organisation for Economic Co-operation and Development; and IMF staff calculations.

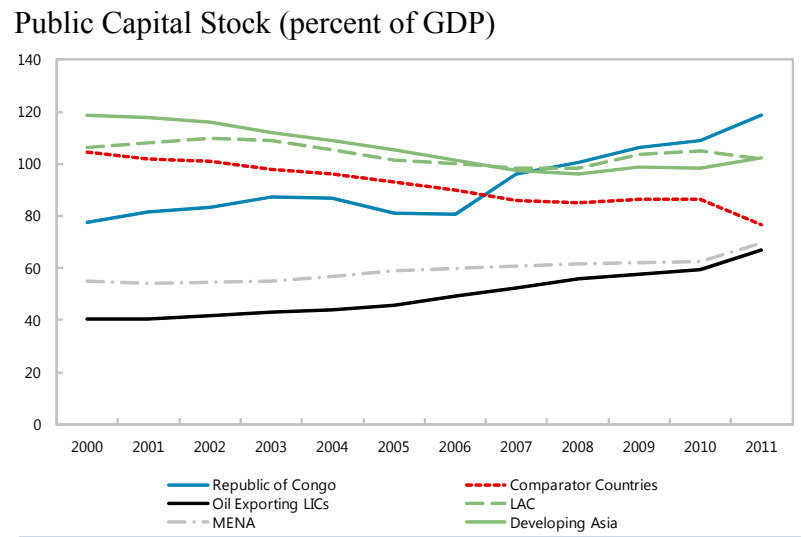

Sources: Center for International Comparisons; Organisation for Economic Co-operation and Development; and IMF staff calculations.

Education spending and service provision have recently increased significantly. Public resources allocated to the education sector were limited in 2010 compared with other SSA countries and countries in the same income level range (Figure 11). In addition, the composition of education spending was somewhat regressive. Primary education tends to be more progressive, because lower-income groups have greater access to this level of education. But the share of expenditure allocated to secondary and tertiary education in the Republic of Congo was higher than in countries with a comparable income level. In addition, although Congo was performing comparatively well as regards the gross enrollment rate, the average class size in 2010 was significantly higher than in countries with comparable GDP per capita, raising questions about service quality. Cognizant of these weaknesses, the government has progressively increased its education spending. The share of the budget allocated to the education ministries has risen from 6.1 percent in 2012 to 8.9 percent in 2014, with a nominal increase of 57 percent over the same period.

\section{Health spending and in-kind services have not compensated for large income and} geographic inequalities. In 2010, health spending in Congo was among the lowest in the SSA region (Figure 12). As a result, the country's reliance on out-of-pocket spending, at 64 percent of total health financing, was among the highest in the SSA region, according to the World Bank. Service provision is insufficient and access to health care professionals limited, particularly in rural areas, which are also the poorest. Health inequality is high, with households in the lowest 20 percent of the income distribution suffering from significantly higher child mortality than the richest 20 percent. 


\section{Figure 11. Education Spending and Outcomes in 2010}

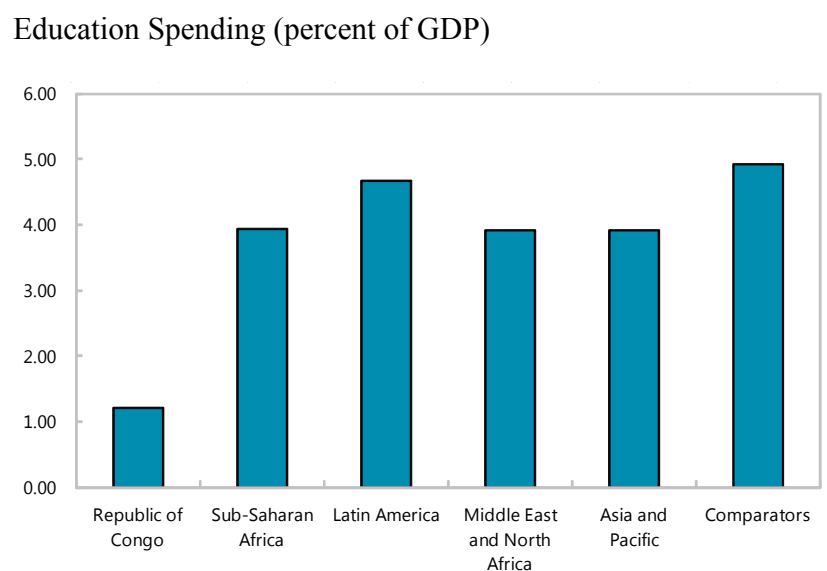

Education Spending by Level (percent of total education spending)

Gross Enrollment Ratios

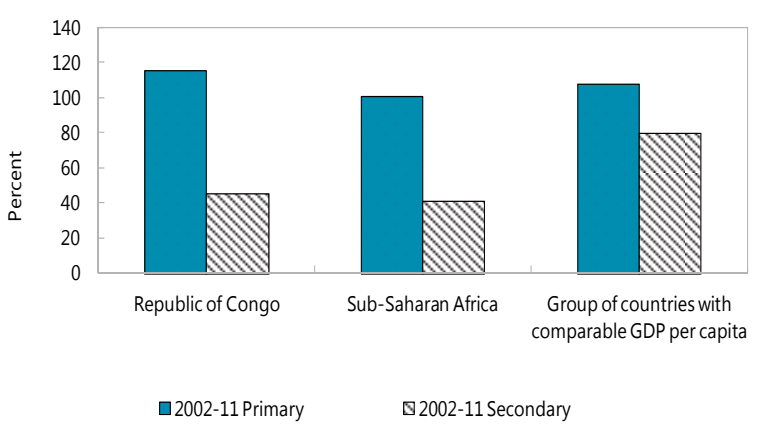

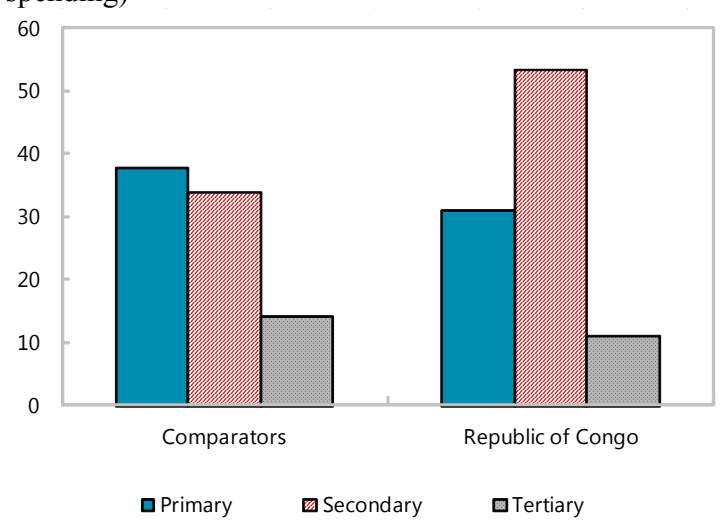

Average Class Size-Primary (number of pupils)

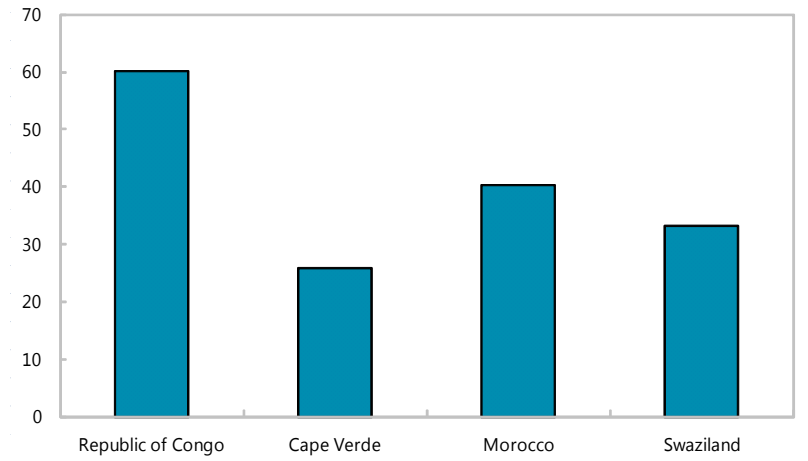

Source: World Bank.

The government has committed to implementing a system of universal health care insurance. While budget allocations have increased for the education sector, they decreased for the Ministry of Health between 2012 and 2014 both in nominal terms (by 1.6 percent) and as a share of total budget spending (by 1.3 percentage points). However, with World Bank support, the government is expected to spend US\$100 million over the next five years, with the aim of implementing universal health coverage. This program would include fee waivers for the poorest households, as well as free service provision. Its financing has not yet been determined and will depend on funding from household contributions and government subsidies to the poorest households. 


\section{Figure 12. Health Spending, Service Provision, and Inequalities}

Health Spending in 2010 (percent GDP)

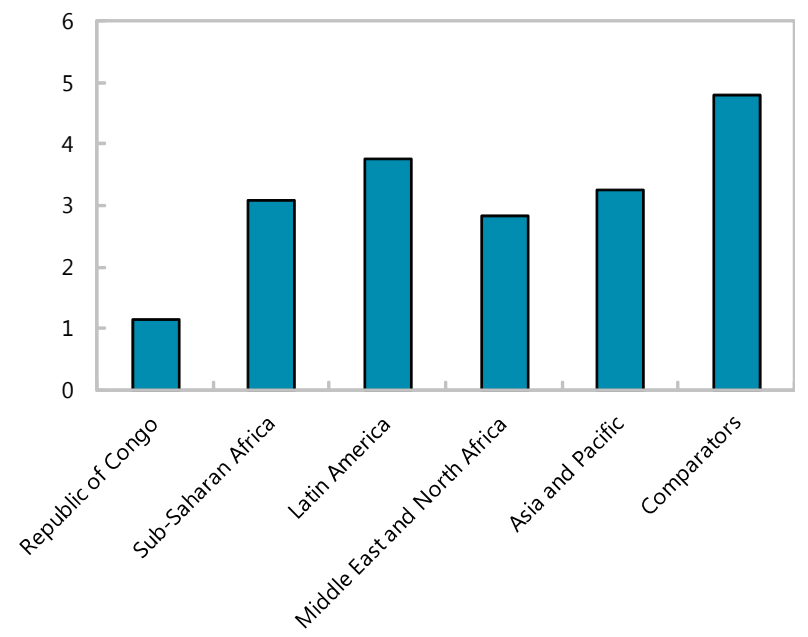

Source: World Health Organization.

Child Mortality Rates and Income Distribution (2011-12)

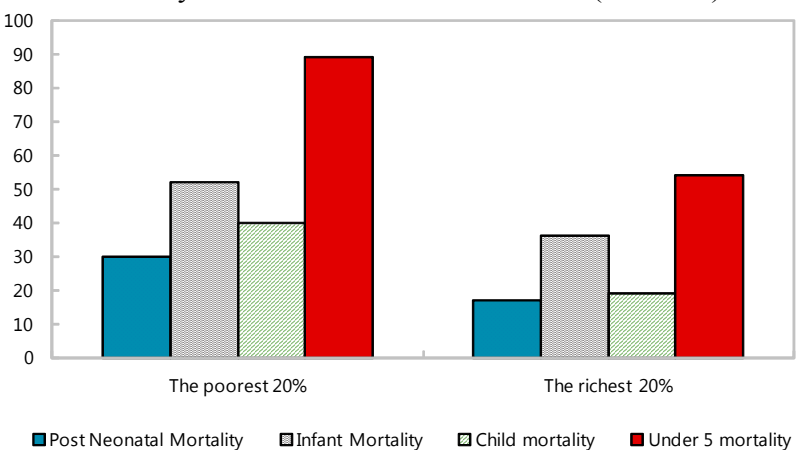

$\square$ Post Neonatal Mortality $\square$ Infant Mortality $\square$ Child mortality $\quad$ U Under 5 mortality

Source: Government of the Republic of Congo, Demographic and Health Survey, 2012.
Health Care Professionals in 2010 (per 1,000 people)

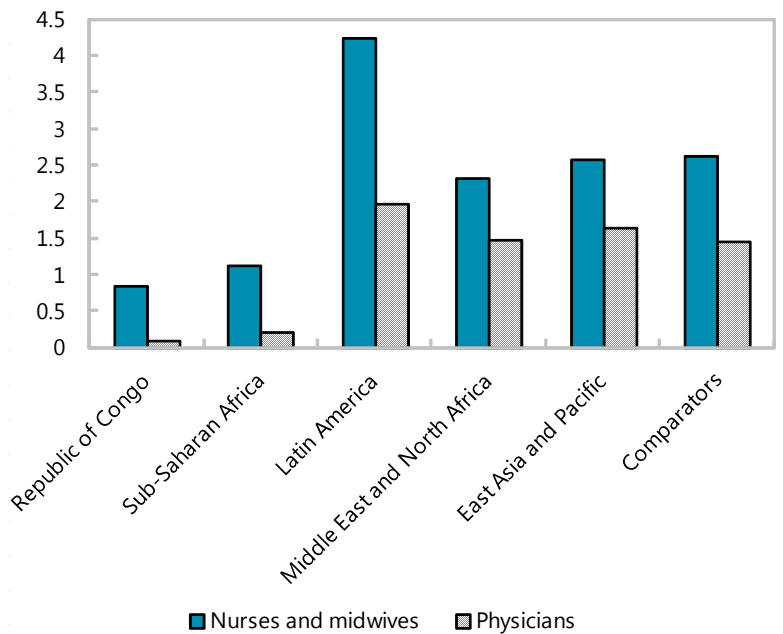

Source: World Health Organization.

Regional Density of Qualified Workers (per 1,000 people)

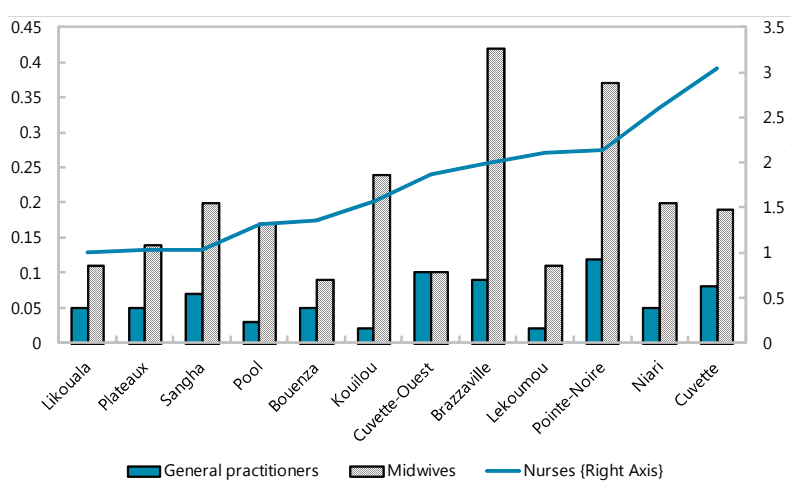

Source: Government of the Republic of Congo, Demographic and Health Survey, 2012.

The Republic of Congo has also started implementing social safety net programs. Safety net spending in Africa has increased since 2005 following food and financial crises and increased donor support. ${ }^{11}$ Congo got a late start compared with other SSA countries, but is now preparing temporary income-generating activities for unemployed youth and labor-intensive, self-employment, and rural employment programs. In addition, a pilot conditional cash transfer program (Lisungi project) is being rolled out for 5,000 poor households and 1,000 elderly people. The cost of expanding this program on a national scale is estimated at about 1 percent of GDP (Box 1).

${ }^{11}$ See World Bank 2014. 


\section{Box 1. Initiating a Social Safety Net through Cash Transfers}

To address the challenges of high poverty and inequality, the Congo government is focusing on the development of a social safety net for poor and vulnerable groups. In its initial phase the fouryear social safety net program (Lisungi project) will make conditional cash transfers to 5,000 poor families and 1,000 people over 60 in three areas (Brazzaville, Pointe-Noire, Cuvette). Eligible households are those living below the food poverty line and with at least one child (between the ages of 0 and 14 years) or an elderly person. Transfers to the households will be conditional on continuous schooling of children and regular health checks for all household members. The program will be monitored and evaluated regularly. Depending on its effectiveness, the program's coverage will be expanded to all eligible households in 2016.

The conditional cash transfer program is expected to improve the Republic of Congo's social and economic indicators in three ways. First, the transfers are expected to reduce current poverty, reaching families that do not directly benefit from economic growth. Second, because they are conditional on education and health spending, they should have a positive impact on school enrollment rates and on child nutrition, thereby improving human capital. Finally, household productivity should improve because the collateral provided by the cash transfers will help families invest in economic activities and gain access to microcredit. Higher employment and social cohesion should ensue.

The Lisungi project mimics similar programs in other countries, such as in Brazil, Colombia, Ghana, Kenya, Mexico, and Niger. The success of these programs is directly related to the quality of the management information system and direct and regular payments to recipients.

An impact analysis carried out by the World Bank suggests that the cash transfer program could have a significant impact on poverty and inequality. It is expected that the poverty rate would decline from 46.5 percent in 2011 to 38.9 percent-3.9 percentage points above the Millennium Development Goals Initiative target (35 percent by 2015) -if the program were to operate nationwide. The Gini index of inequality would also drop between 8 and 11.8 percent. Implementing the program on a national scalewith payments of CFAF $20,000-25,000$ on average a month to the poorest households with children and/or elderly members-would cost about 1 percent of GDP or about 2 percent of public expenditure.

The main contributor to this box is Dalia Hakura, based on World Bank 2013.

\section{Strategy for an Equitable Fiscal Consolidation}

Fiscal consolidation should be based on progressive tax and spending measures to protect vulnerable households during adjustment. In LICs, while fiscal adjustment can have an adverse effect on employment and inequality in the short term, this effect may be reversed in the long term. Inequality and unemployment may even decline over the longer term if fiscal adjustment helps bring down inflation-which is damaging to the poor-or corrects macroeconomic imbalances that are hindering growth. And because spending in developing 
economies is generally not progressive, cutting such spending can ensure fiscal consolidation while avoiding a surge in inequality. ${ }^{12}$ Hence, fiscal policy should aim at balancing the provision of much needed public services with fiscal sustainability, through tax revenue mobilization and prioritization of spending. The government should not resort to across-the-board spending cuts, which can hurt low-income groups. It should instead focus on improving the composition and efficiency of spending to prevent spending restraint from affecting the quantity or quality of basic services.

\section{A better-functioning personal income tax system would enhance tax progressivity.} Strengthening the personal income tax yield can raise the tax ratio while strengthening progressivity. Implementing a zero-tax bracket for the lowest incomes would both simplify revenue administration and enhance tax progression. Reducing tax deductions is also needed, because they accrue disproportionately to the rich and lead to significant revenue losses. Large tax deductions on salary income should be eliminated and further reduced for professional expenses. The family tax system benefits based on the number of dependents (quotient familial) is a major hindrance to income tax equity because it favors large high-income families and should be replaced with a fixed tax credit that is the same for all taxpayers. In addition, there is no need for a tax incentive to increase the fertility rate in the Republic of Congo, which is among the highest in the world. Deductions for mortgage interest and capital income should also be eliminated: only high-income households are able to borrow from banks and receive financial earnings.

Develop property taxes. There is a large scope for increasing this tax in Congo. This reform could have a significant redistributive impact. To make it progressive, the tax could exclude the permanent residence of those below a certain threshold to prevent taxation of low-income households. Property tax could be implemented gradually given that it requires a reliable land registry and the administrative capacity to manage it.

Minimize the use of reduced value-added tax (VAT) rates and exemptions. Achieving redistributive objectives through consumption taxes usually proves to be costly. The rich generally spend more in absolute terms, so they tend to benefit more from exemptions or reduced VAT rates. Congo uses these instruments extensively for necessities, in particular on a large variety of food products and agricultural inputs. There is also an exemption for electricity and water consumption, which is particularly regressive, since only 37.8 percent of the population had access to electricity in 2011. Reducing the list of goods exempt or benefiting from reduced VAT rates would help raise revenues that could be used to increase targeted social transfers, administrative capacity permitting.

\section{As regards expenditure efficiency, the government should aim at cutting general}

subsidies. Reducing or eliminating fuel subsidies would create fiscal space for social spending. It would improve the progressivity of public spending, since higher-income households consume more petroleum products. However, it would have a negative impact on the poorest households, because energy consumption represents a large share of their total consumption.

${ }^{12}$ IMF 2014a. 
Implementing this reform gradually and compensating vulnerable households would be critical to success. ${ }^{13}$ In particular, interventions targeted to vulnerable households through conditional cash transfers would be needed. But designing such programs requires significantly improving data transparency and reliability for informed policy decision making. Other mitigating measures could, for example, take the form of subsidies for public transportation.

\section{Containing the public wage bill and spending on goods and services could provide} additional fiscal space for social spending. Purchases of goods and services (9.8 percent of non-oil GDP) are much higher in Congo than the average for oil-exporting LICs (6.9 percent) and other CEMAC countries (excluding Gabon). Some expenditure reform is needed in this area (Figure 13). The wage bill in Congo (9.8 percent of non-oil GDP) is also higher than in most other CEMAC countries. Progressive containment of the wage bill would help create fiscal space for social spending. The strategy should aim for adequate recruitment in the health and education sectors and reduced hiring in nonpriority sectors through natural attrition.

\section{A change in the composition and level of public investment could also provide room for} additional social spending. The capital stock accumulated in Congo by 2011 was significantly higher than in countries with similar income levels and almost twice the average of oil-exporting LICs. In addition, capital spending pressures will increase with the organization of the 2015 All Africa Games in Congo. The proposed long-term path aims at stabilizing the capital-stock-toGDP ratio at its 2011 level. The composition of public investment, which was largely concentrated on infrastructure, could also be geared toward social sectors to improve service provision. This approach will require evaluating current expenditure needs associated with the increase in education and health infrastructure.

\section{Improving access to in-kind services by low-income groups would help reduce poverty and inequality and boost growth in the long run. In the education sector, the government} should prioritize spending on primary schools and improve service quality, in particular through recruitment of additional teachers to close large staffing gaps (estimated at 14,000 teachers by the Primary National Education Council). In the health sector, the fiscal costs of the introduction of universal health coverage should be carefully assessed. The implementation should be sequenced to increase household coverage progressively while mitigating the impact on fiscal aggregates. Plans should be made in particular to determine the level of noncontributory coverage to protect population groups unable to afford insurance, while containing fiscal costs. Progressivity should also be embedded in the design of social contributions to finance the health care system - a flat price would weigh disproportionately on those who are less well off. And in order to reduce poverty and inequality, the system should focus on expanding access to a broad package of essential health services for poor households; reducing health copayments and user charges for low-income households; and ensuring access to health care facilities and professionals, particularly in rural areas.

\footnotetext{
${ }^{13}$ See Alleyne 2013.
} 
Figure 13. Selected Current Expenditure in 2013

(Percent of non-oil GDP)

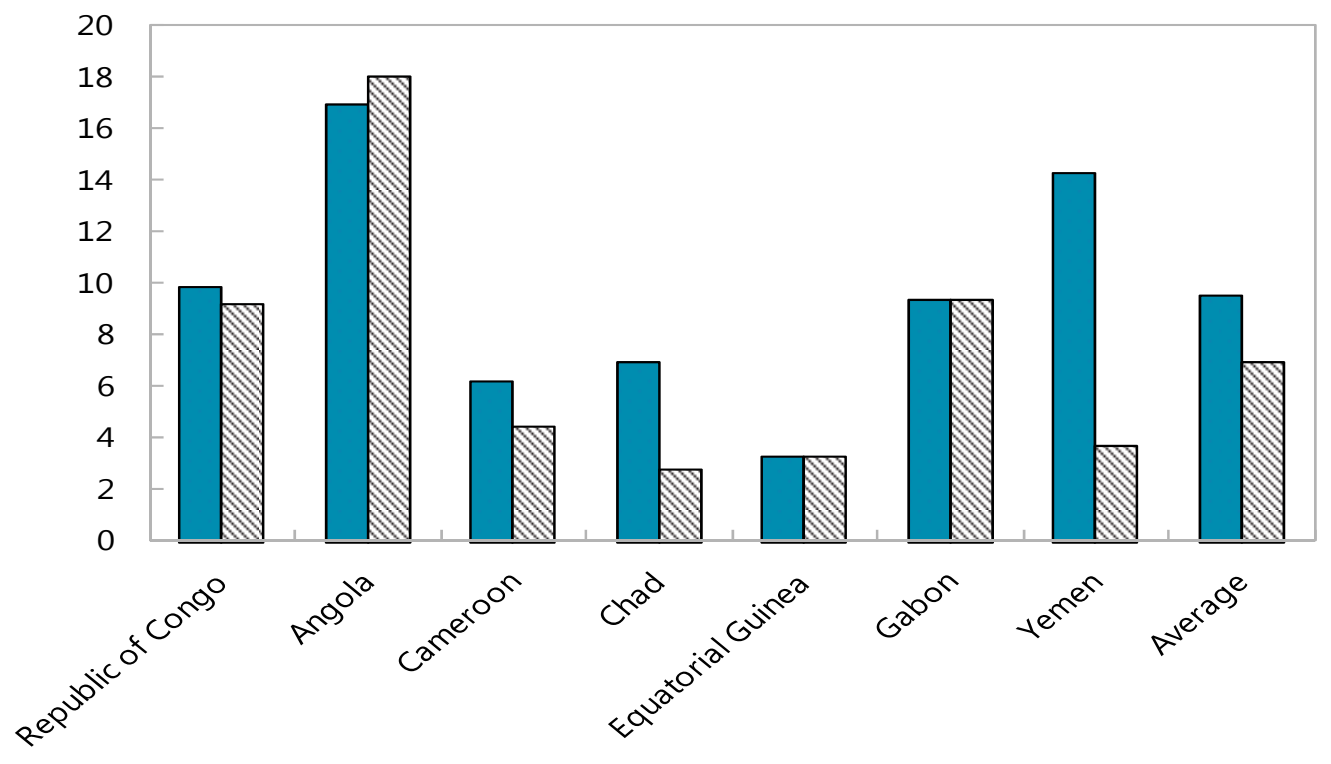

$\square$ Wage bill $\otimes$ Goods and services

Source: IMF staff estimates.

Ensure adequate design of new social safety nets. The Republic of Congo is in the initial steps of designing new safety net programs, so it should be mindful of design and implementation shortcomings that have been observed in other LICs. In particular, Congo should avoid fragmenting and duplicating small social programs and guard against bad targeting, which can cause substantial leakage for nonpoor households and result in insufficient benefits for the most vulnerable people. 


\section{Financial Sector: Risks, Development, and Inclusion}

In the aftermath of the global financial crisis, sub-Saharan Africa is emerging as a fastgrowing region. It is attracting investors from all over the world and raising its people's standard of living. Nonetheless, limited access to finance is still holding down the standard of living in the region and hindering poverty alleviation.

Striking the appropriate balance between maintaining financial stability, managing financial risks, and fostering a competitive and inclusive financial environment is a critical policy issue. On the one hand, financial inclusion - that is, the share of people and firms with access to financial services - can help lower poverty by reducing credit constraints on the poor. In particular, when markets open up, finance can help small firms, entrepreneurs, and households reach new opportunities. Furthermore, people and firms with access to financial products can better manage their risk (for example, loans to smooth consumption and purchase durable goods and agricultural insurance products). On the other hand, improving financial development does not mean lax lending standards. Rapid credit growth, weak supervision, and defective regulatory frameworks can easily trigger financial instability.

As of 2012, almost three-quarters of the SSA adult population lacked access to formal financial services, compared with the rest of the world, where about 50 percent of adults had a formal financial account. The Republic of Congo's metrics related to financial development and inclusion are below even the SSA averages. Like many other SSA countries, Congo seeks to make inroads against poverty by incorporating those who are outside the formal financial system. Rapid diffusion of information and communications technologies in African countries is associated with growth in telephone subscribers, personal computer users, and Internet access faster than in other developing regions of the world. ${ }^{14}$ Mobile phone banking in Congo today provides an opportunity to reach mass markets in an efficient and effective manner.

\footnotetext{
${ }^{14}$ Andrianaivo and Kpodar 2011.
} 
This chapter argues that a deeper and more inclusive financial sector in Congo could help reduce poverty and improve the standard of living of its citizens. Based on the information in a comprehensive World Bank database, this chapter highlights critical issues in Congo related to financial inclusion and development and discusses possible policy implications, including financial risk mitigation. The chapter places access to financial services by the people of Congo in the SSA context by comparing several metrics with its peer countries and by discussing the role of new technologies in promoting financial inclusion-by stressing the potential of mobile banking in the country. ${ }^{15}$

\section{A Comparative Analysis}

Underdevelopment of financial services and lagging financial inclusion are chronic problems in the Republic of Congo, as is true in other SSA countries. Recent research shows that the SSA region suffers from a "financial development gap"—-measured by comparing financial development indicators with those in countries at a similar stage of overall economic development. ${ }^{16}$ Only 9 percent of the total adult population has a formal financial account, placing Congo behind the CEMAC average (Figure 14, panel 1). Financial inclusion can be highlighted also from the perspective of the contrast between the bankable "better-off" and "poor."17 In Congo, 20 percent of the better-off population has a formal account compared with only 1.1 percent of the poor. The ratio of bankable better-off to poor people is about 18 , making Congo one of the least financially inclusive in the SSA region (Figure 14, panels 2 and 4).

Lack of financial access and wealth inequality are closely associated. For example, access to loans and insurance creates heterogeneous opportunities for businesses and growth. ${ }^{18}$

Moreover, diversifying income sources to include interest and dividend payments can augment returns and build wealth. ${ }^{19}$ Thus, when the better-off population enjoys better access to financial services than the poor they have a better chance of becoming richer, tilting the income distribution accordingly. The latest reported Gini coefficient (0.39 in 2011) from the World Bank shows that income inequality in Congo is similar to that in Cameroon, Chad, and Gabon. Shallowness can be traced back to a lack of progress in improving the availability of creditor information and protecting investors' rights (Singh, Kpodar, and Ghura 2009).

The aspect of financial inclusion related to gender inequality reveals a clear pattern in the SSA region. Women in Congo have much less access to financial services. Only 6.8 percent of women have a formal financial account compared with 11.3 percent of men. The ratio of men to

\footnotetext{
${ }^{15}$ Among others, Demirgüç-Kunt and Klapper (2012a) look as well at financial inclusion in Africa.

${ }^{16}$ See for example Allen and others (2012a).

${ }^{17}$ The "bankable" population refers to the share of the adult population with access to a formal financial account. The "better-off" and the "poor" are the top quintile and bottom quintile, respectively, of the adult population ranked by income.

${ }^{18}$ For a discussion about the link between finance and growth see Levine 2005.

${ }^{19}$ Piketty (2003) shows that the composition of the top 1 percent of the population by income is dominated by income flows related to rents, interest, and dividends.
} 
women holding accounts is about 1.66 and is much higher than in SSA frontier and emerging market economies, where this ratio is only 1.22 (Figure 14, panel 3). ${ }^{20}$

Mobile banking, as an alternative to traditional forms of financial services, is well represented in Congo (Figure 14, panel 5). A recent survey found that almost 40 percent of the adult population has, on occasion, used mobile phone services to make financial transactions, pay bills, or transfer or borrow money. This is the second highest share in the CEMAC and CFA franc areas after Gabon and the fourth highest in the SSA region (according to the Global Findex database, Demirgüç-Kunt and Klapper 2012b).

The share of adults with formal savings is hovering around 5.5 percent in Congo. Compared with its CEMAC peers, it is the second lowest after the Central African Republic. Nevertheless, the potential is very high. More than 30 percent of the population has saved money, many informally. This ratio represents the second highest share in the CEMAC region. Most of these savings could be transferred to institutions that are safer and formally regulated (Figure 14, panel 6).

The most important constraint people cite behind not having a formal account is the lack of money (Figure 15, panel 1). This reason is cited more than the averages across CEMAC, SSA, and frontier economies. In this regard, banks in Congo are blamed for imposing strict requirements (for example, documentation) and charging so much for their services (for example, opening and maintenance fees) compared with other banks in the region. These high transaction costs are probably related to the relatively high overhead costs (Figure 16) in Congo.

There is a strong relationship between the average standard of living (measured as GDP per capita) and access to financial services in the SSA region (Figure 15, panel 1). The CEMAC region lags other African countries. For Congo, the financial access corresponding to the level of income is far below the SSA average. Compared with SSA countries, more than 20 percent of the adult population should have access to financial services according to this measure. Similarly, the comparison with the Human Development Index reveals a corresponding potential level of 28 percent of the population (Figure 15, panel 4).

The supply of financial services (proxied by the number of commercial bank branches per capita) corresponds to the SSA average based on the level of financial accounts in Congo. In terms of banking networks, Congo is at the bottom of the list. Countries in the region with more developed networks, such as Gabon (with more than double the number of branches per capita), have a much higher penetration of financial access (about 19 percent).

\footnotetext{
${ }^{20}$ The group of SSA frontier and emerging market economies refers to the following countries: Ghana, Kenya, Mauritius, Nigeria, Senegal, South Africa, Tanzania, Uganda, and Zambia. This group was constrained by data availability.
} 
Figure 14. Republic of Congo: Financial Inclusion Statistics
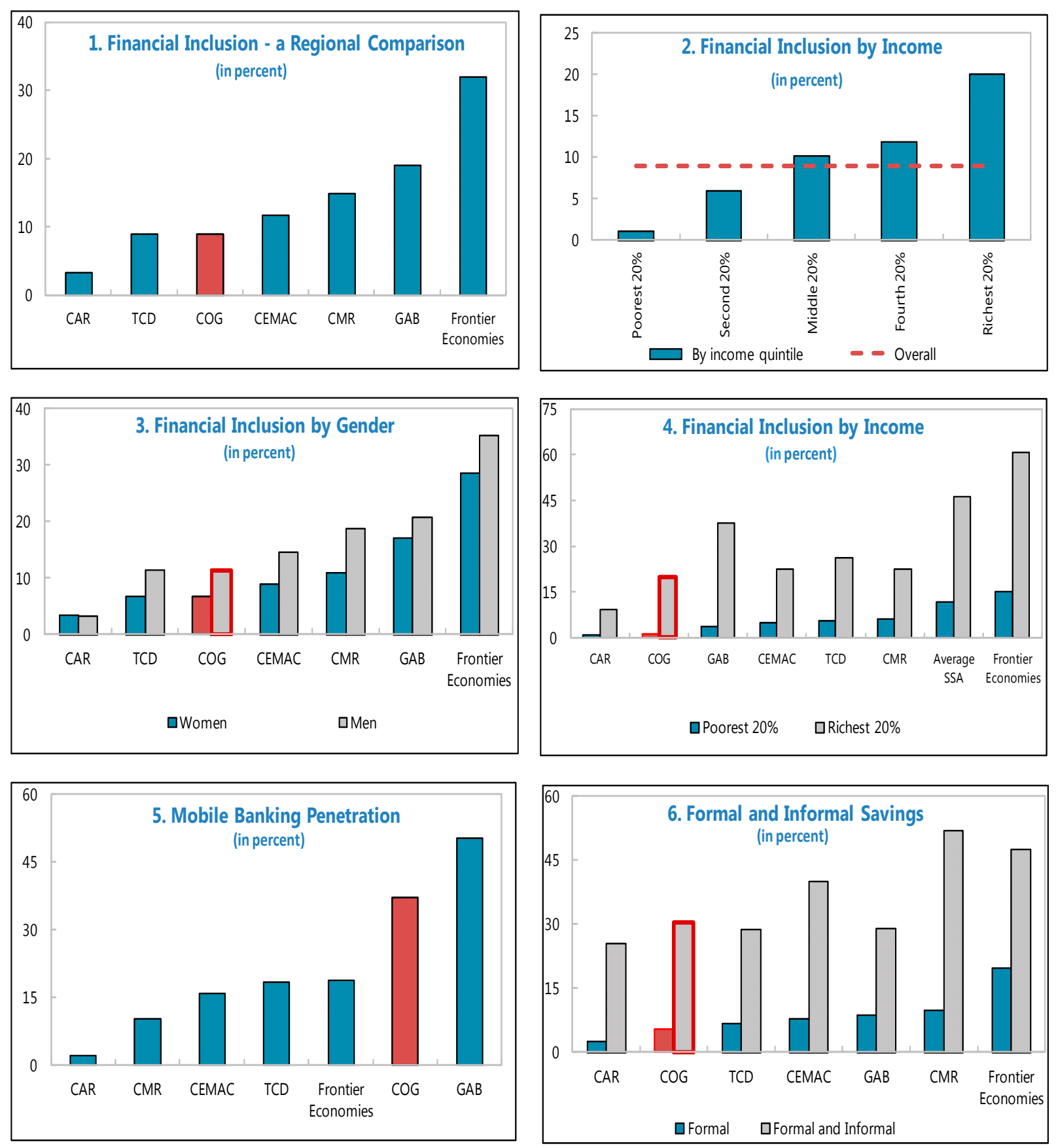

Sources: World Bank Global Findex database; and IMF staff calculations.

Note: $\mathrm{CAR}=$ Central African Republic, $\mathrm{CMR}=$ Cameroon, $\mathrm{CEMAC}=$ Central African Monetary and Economic Community, TCD = Chad, COG = Republic of Congo, GAB = Gabon. 
Figure 15. Republic of Congo: Analysis and Relationships of Financial Access and Development
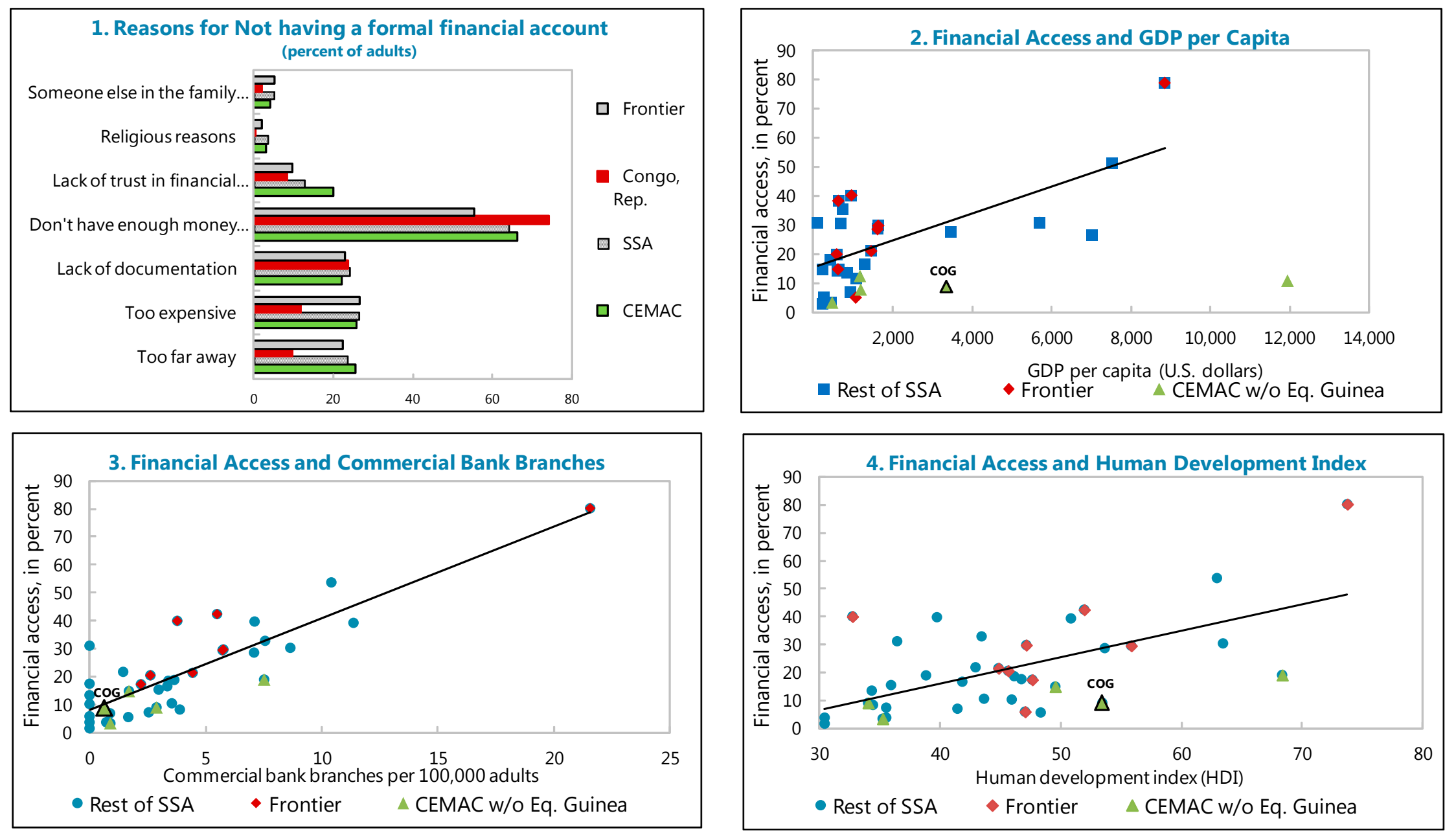

Source: Global Findex database (World Bank) and IMF staff calculations. 


\section{Box 2. Mobile Banking}

Led by rapid mobile phone penetration, mobile banking (monnaie électronique) is emerging as an innovative financial product in the Republic of Congo and CEMAC area. At the end of 2013, there were only two active banks in Congo: BGFI Bank and Ecobank, each working in collaboration with a telecommunications operator (Airtel and MTN Congo, respectively). The market has recently been liberalized, and telecom operators are now able to collaborate with several financial institutions.

The mobile banking market has developed considerably in recent years, enhancing financial access. The number of active users with one of the banks almost tripled last year. In 2013, the electronic monetary base at this institution averaged CFAF 385 million, and the transaction volume peaked in the third quarter at about CFAF 8.5 billion (Figure 2.1).

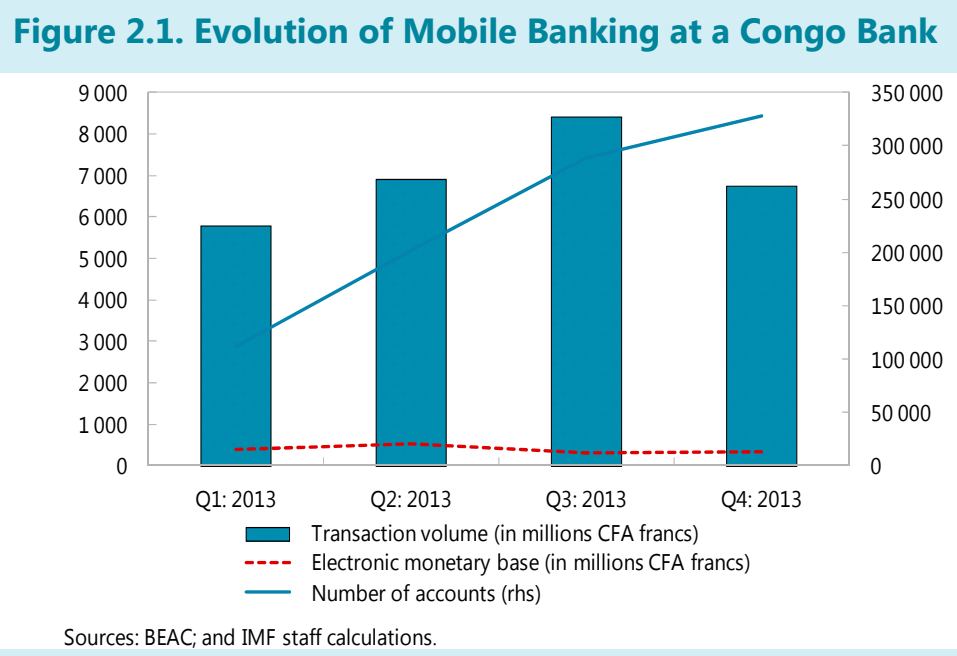

Fees are more competitive than those of traditional banks. Transactions from a bank account to a mobile bank account are free of charge. The other way around, transaction fees vary depending on the amount transferred and can be as low as 0.2 percent. The costliest operation is cash withdrawal, which can carry a fee as high as 4 percent.

Risks related to mobile banking are mainly operational. The telecom operator must collateralize the entire monetary base in an escrow account at the partner bank. Given the steady increase in the number of operations, operational risks could be addressed by the following (see Khiaonarong 2014):

- Including mobile transfers in the payments system regulatory framework to ensure customer protection;

- Updating the coverage of operational risks-such as potential disruptions or compromises to system integrity-as more operators enter into the market;

- Implementing anti-money-laundering/combating the financing of terrorism measures to safeguard mobile payment systems from financial crime; and

- Coordinating with other CEMAC countries' cross-border payments and, in particular, risk controls in interbank payment systems. 


\section{The banking sector lacks depth and remains small and concentrated, with relatively high overhead costs:}

- Although deposits and credit have grown rapidly in recent years, they remain small in proportion to GDP (Figure 16). ${ }^{21}$ The growth in deposits reflects the intensification (increase) in operations related to issuance of new instruments. Deposits are short term, as are loans, thereby avoiding maturity mismatch. On the one hand, credit to the private sector, which is below the 2012 benchmarks for low-income countries, remains negligible, hovering around 10 percent of GDP. ${ }^{22}$ While bank intermediation should be a critical aspect of financial deepening and economic growth, it has yet to happen in Congo. ${ }^{23}$ On the other hand, the ratio of deposits to GDP stood at 25 percent at the end of 2013. As a consequence, the loanto-deposit ratio, which currently stands at 40 percent of GDP, has shown lackluster improvement since 2005, remaining below the benchmark for comparable countries.

- The financial sector is dominated by commercial banks, which are, mostly, privately owned subsidiaries of foreign institutions. The number of banks increased from six in 2010 to ten in 2013, including the state-owned Banque Congolaise de I'Habitat and the Banque Postale du Congo, which started operations in January 2013. The three largest commercial banks have almost 60 percent of total assets in the banking system, well below the benchmarks and all other CEMAC countries. Nonetheless, commercial bank network development has not been robust, and the number of commercial bank branches remained well below the benchmark for similar countries.

- Overhead costs remain high, not just compared with other CEMAC countries but with benchmarks as well. The financial infrastructure constraints contribute to high overhead costs, which have increased compared with the 2005 data. Shortcomings in credit information lead to higher screening costs for financial institutions, translating into higher overhead. Similarly important is the ease of enforcing contracts and the cost involved. The longer it takes to foreclose on collateral and the more uncertain and expensive the process, the lower the actual value of the collateral provided by the borrower and the higher the risk premium the bank charges for the loan.

\footnotetext{
${ }^{21}$ The benchmark represents the median value of a set of countries with similar GDP-per-capita characteristics.

${ }^{22}$ Short-term credit is concentrated in extractive industries' activities, public sector work (Bureau of Public Works and Civil Engineering), and electricity. Long-term credit is negligible. At the end of 2013, credit to the private sector totaled CFAF 763.9 billion and represented 73.3 percent of total gross credit compared with 83.6 percent in 2012.

${ }^{23}$ The lack of collateral is one handicap of great economic importance for Congo. Land titles are not available, and property rights are not firmly established.
} 


\section{Figure 16. Selected Indicators of Financial Development and Risks}
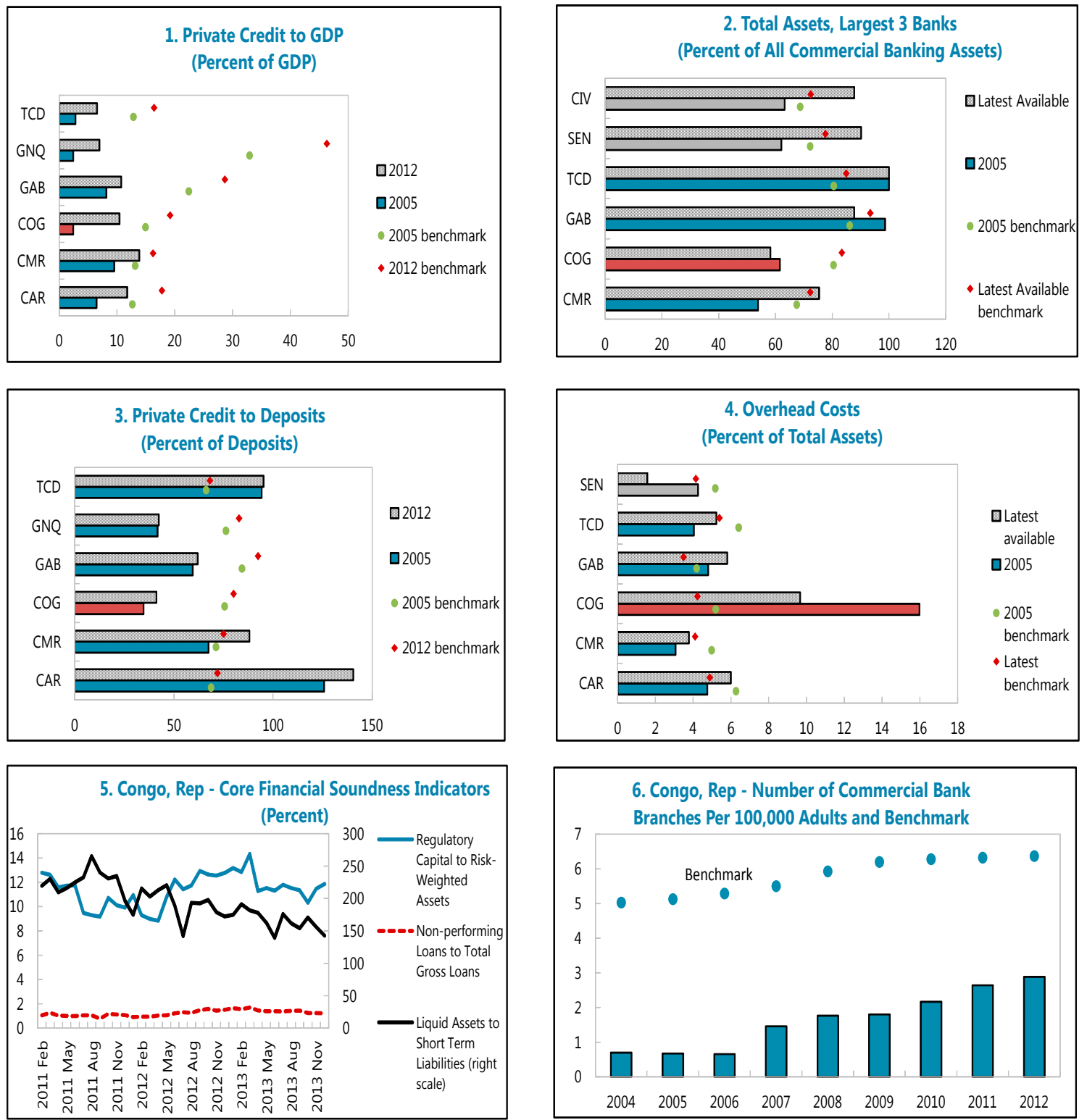

Sources: World Bank, World Development Indicators (WDI) database; country authorities; and IMF staff calculations.

Note: $C A R=$ Central African Republic, $C M R=$ Cameroon, GNQ = Equatorial Guinea, $T C D=C h a d, C O G=$ Republic of Congo, $\mathrm{GAB}=$ Gabon, SEN = Senegal, CIV = Côte d'Ivoire. 
Banks remain highly liquid (Table 2). At the same time, banks maintain large deposits at the BEAC. This excess liquidity is a result mainly of the difficulty in identifying sufficient lending opportunities, absence of a domestic securities market, and lack of a proper legal framework and a well-functioning judicial system. However, one Congo bank has subscribed to bond issuances of Gabon and Cameroon. In particular, it participated in more than 11 percent of Cameroon's issuance from November 2011 to November 2013 and 15 percent of Gabon Treasury bill issuance during 2013. These transactions indicate the search for yield by banks in the region and the need to develop a regional market for government securities.

\section{Congo's insurance market has developed significantly in recent years supported by} vigorous economic activity in the country. Four companies now operate in the market. As of the end of June 2013, collective turnover stood at CFAF 25.8 billion. The forecasts for all four companies for 2013 call for turnover of CFAF 16.1 billion. Three main factors account for this expansion: the opening of the market to competition, structural development (improving the penetration rate, which was barely 0.6 percent in 2012), and the expansion of the scope of insurance requirements in 2013. In addition to automobile liability and construction risk policies, coverage requirements were imposed for imported merchandise, creating the conditions for the development of transportation insurance.

The banking system is sound, showing satisfactory compliance with CEMAC prudential ratios (see Table 2). The ratio of nonperforming loans (NPLs) to total loans has remained low during the past decade, and banks have maintained capital above the minimum levels (8 percent). Nevertheless, rapid credit growth-fueled by activity in construction, transportation, telecommunications, and tourism-poses risks: banks could loosen their standards in an attempt to gain market share. Furthermore, some banks are not respecting limits (thresholds) regarding individual lending. Although profitability has shown a remarkable path in recent years in a rapidly growing banking system, dividend and profit repatriation has also been high, signaling limited domestic investment. Return on assets and on equity ratios improved in 2013 to reach 1.9 and 20.8, respectively. Notwithstanding a decrease in gross NPLs to 2.3 percent in 2013-after reaching 2.9 percent in 2012-banks' provisioning in relation to NPLs continued to deteriorate in 2013. 
Table 2. Financial Soundness Indicators of the Banking Sector, 2009-13

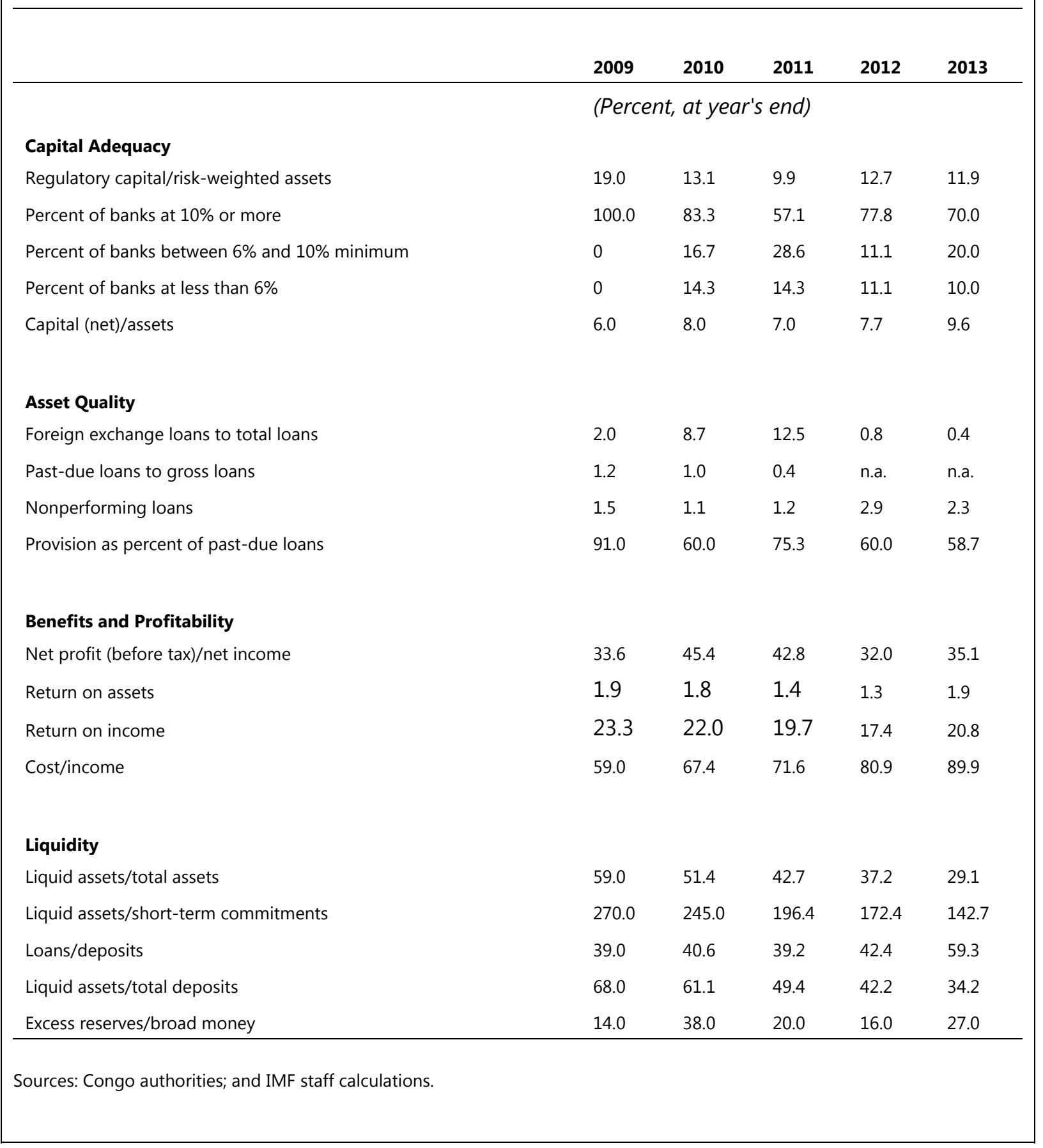


The microfinance environment in Congo is expanding-dominated by the network of credit unions-and remains relatively concentrated in Brazzaville and Pointe-Noire. ${ }^{24}$ The sector includes 62 institutions - the majority in Brazzaville (23) and Pointe-Noire (13). In addition,

- MUCODEC institutions represent more than half of all microfinance institutions (33). Between 2009 and 2012, the total customer base increased by 10 percent on average in the sector to reach 344,000 at the end of 2012. Close to four-fifths of customers are affiliated with the MUCODEC network. The microfinance sector employs 1,499 people, of whom one-third work for the MUCODEC.

- Over the period 2009-12, the rate of growth of deposits (averaging 17 percent a year) outpaced that of credit (2 percent). Deposits increased from CFAF 125.3 billion in 2009 to CFAF 191.9 billion in 2012, more than 80 percent going to the credit union network. While credit increased by 7 percent between 2011 and 2012, deposits grew by 20 percent. Over 80 percent of credit is from MUCODEC institutions.

The microfinance sector is increasingly important in the Republic of Congo, and an effective implementation by the Central African Banking Commission-the institution in charge of banking supervision and regulation in the CEMAC region-of prudential rules is critical at this stage. Microfinance accounts for a significant and probably increasing share of deposits and credit in the country, but the exact size is difficult to assess. However, there is room to continue to strengthen corporate governance and management practices and the sector's regulatory framework.

The policy agenda should include measures to address the main barriers to financial access. Improving legislation, property rights, and documentation (such as related to the establishment of a well-functioning national credit registry and the registration of land ownership) should increase access to finance. The efforts to create a good environment for microfinance and mobile banking should continue by fostering collaboration between commercial banks and microfinance institutions and telecommunications companies. Ongoing implementation of the electronic payment system for taxes and utilities must move forward, and development of the bank branch network should be encouraged. ${ }^{25}$

\footnotetext{
${ }^{24}$ Mutuelles Congolaises d'Épargne et de Crédit (MUCODEC).

${ }^{25}$ For a more detailed discussion of the policy recommendations for financial development in Africa see Allen and others $2012 \mathrm{~b}$.
} 
This page intentionally left blank 


\section{Some Takeaways}

The Republic of Congo has enjoyed strong economic growth driven by a large public investment program financed through sizable oil revenues. However, this growth has not been inclusive and almost half of the population lives in poverty. At the same time, because of the country's limited oil reserves, fiscal policy should focus on preserving long-term macroeconomic stability. This paper has examined three different aspects of Congo's challenge to managing its natural resource revenue and attaining sustained inclusive growth. The main findings are as follows:

- IMF Debt, Investment, Growth and Natural Resources model simulations highlight the importance of a prudent approach to public investment in the Republic of Congo that aims at enhancing the efficiency of investment.

- Fiscal consolidation can contribute to achieving distributional objectives through tax and expenditure policy reforms.

- The financial sector is underdeveloped, and financial access is among the lowest in the CFA franc area. Policy measures are needed to address the main barriers to financial development and access, including by improving legislation, property rights, and documentation (such as related to the establishment of a well-functioning national credit registry and the registration of land ownership) to support access to finance. 
This page intentionally left blank 


\section{References}

Allen, Franklin, Elena Carletti, Robert Cull, Jun Qian, Lemma Senbet, and Patricio Valenzuela. 2012a. "Resolving the African Financial Development Gap: Cross-Country Comparisons and a Within-Country Study of Kenya." NBER Working Paper 18013, National Bureau of Economic Research, Cambridge, Massachusetts.

Allen, Franklin, Asli Demirgüç-Kunt, Leora Klapper, and Maria Soledad Peria. 2012b. "The Foundations of Financial Inclusion: Understanding Ownership and Use of Formal Accounts." World Bank Policy Research Working Paper 6290, World Bank, Washington.

Alleyne, Trevor. 2013. "Energy Reform in Sub-Saharan Africa, Experience and Lessons." African Department Report 13/2, International Monetary Fund, Washington.

Andrianaivo, Mihasonirina, and Kangni Kpodar. 2011. "ICT, Financial Inclusion, and Growth: Evidence from African Countries." IMF Working Paper 11/73, International Monetary Fund, Washington.

Arze del Granado, Javier, David Coady, and Robert Gillingham. 2010. "The Unequal Benefits of Fuel Subsidies: A Review of Evidence for Developing Countries." IMF Working Paper 10/202, International Monetary Fund, Washington.

Berg, Andrew, Rafael Portillo, Shu-Chun S. Yang, and Luis-Felipe Zanna. 2013. "Public Investment in Resource-Abundant Developing Countries." IMF Economic Review 61 (1), 92-129.

Buffie, Edward F., Andrew Berg, Catherine Patillo, Rafael Portillo, and Luis-Felipe Zanna. 2012. "Public Investment, Growth and Debt Sustainability: Putting Together the Pieces." IMF Working Paper 12/177, International Monetary Fund, Washington. 
Demirgüç-Kunt, Asli, and Leora Klapper. 2012a. "Financial Inclusion in Africa: An Overview." World Bank Policy Research Working Paper 6088, World Bank, Washington.

_ 2012b. "Measuring Financial Inclusion: The Global Findex Database." World Bank Policy Research Working Paper 6025, World Bank, Washington.

International Monetary Fund (IMF). 2012. "Republic of Congo: Poverty Reduction

Strategy Paper." IMF Country Report 12/242, International Monetary Fund, Washington.

_. 2014a. "Fiscal Policy and Income Inequality." IMF Policy Paper, International Monetary Fund, Washington.

_ 2014b. "Republic of Congo: 2014 Article IV Consultation—Staff Report." IMF Country Report 14/272, International Monetary Fund, Washington.

Khiaonarong, Tanai. 2014. "Oversight Issues in Mobile Payments." IMF Working Paper 14/123, International Monetary Fund, Washington.

Levine, Ross. 2005. "Finance and Growth: Theory and Evidence," in Handbook of Economic Growth, edited by Philippe Aghion and Steven Durlauf. Amsterdam: NorthHolland Elsevier.

Melina, Giovanni, Shu-Chun S. Yang, and Luis-Felipe Zanna. 2014. "Debt Sustainability, Public Investment and Natural Resources in Developing Countries: The DIGNAR Model," IMF Working Paper 14/50, International Monetary Fund, Washington.

Piketty, Thomas. 2003. "Income Inequality in France, 1901-1998." Journal of Political Economy 111 (5): 1004-1042.

Singh, Raju Jan, Kangni Kpodar, and Dhaneshwar Ghura. 2009. "Financial Deepening in the CFA Franc Zone: The Role of Institutions." IMF Working Paper 09/113, International Monetary Fund, Washington.

World Bank. 2013. Congo, Republic of - LISUNGI Safety Nets Project. Washington.

- 2014. Reducing Poverty and Investing in People: The New Role of Safety Nets in Africa. Washington. 
